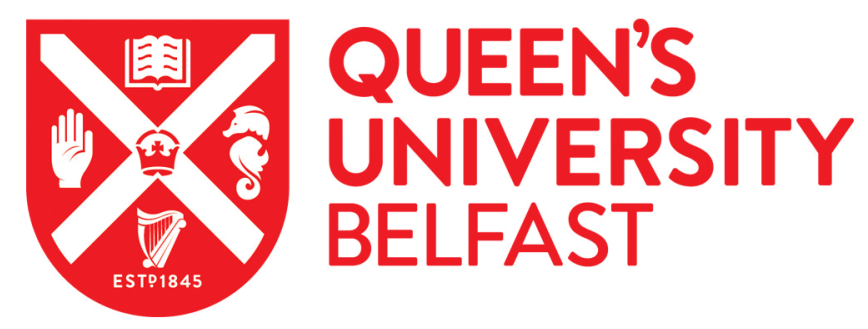

\title{
Direct and interactive effects of climate, meteorology, river hydrology, and lake characteristics on water quality in productive lakes of the Canadian Prairies
}

Vogt, R. J., Sharma, S., \& Leavitt, P. R. (2018). Direct and interactive effects of climate, meteorology, river hydrology, and lake characteristics on water quality in productive lakes of the Canadian Prairies. Canadian Journal of Fisheries and Aquatic Sciences, 75(1), 47-59. https://doi.org/10.1139/cjfas-2016-0520,

https://doi.org/10.1139/cjfas-2016-0520

\section{Published in:}

Canadian Journal of Fisheries and Aquatic Sciences

\section{Document Version:}

Peer reviewed version

Queen's University Belfast - Research Portal:

Link to publication record in Queen's University Belfast Research Portal

\section{Publisher rights}

(C) 2017 Canadian Science Publishing.

This work is made available online in accordance with the publisher's policies. Please refer to any applicable terms of use of the publisher.

\section{General rights}

Copyright for the publications made accessible via the Queen's University Belfast Research Portal is retained by the author(s) and / or other copyright owners and it is a condition of accessing these publications that users recognise and abide by the legal requirements associated with these rights.

\section{Take down policy}

The Research Portal is Queen's institutional repository that provides access to Queen's research output. Every effort has been made to ensure that content in the Research Portal does not infringe any person's rights, or applicable UK laws. If you discover content in the

Research Portal that you believe breaches copyright or violates any law, please contact openaccess@qub.ac.uk. 
2 Direct and interactive effects of climate, meteorology, river hydrology, and lake characteristics on water quality in productive lakes of the Canadian Prairies

11 a Limnology Laboratory, Department of Biology, University of Regina, Regina, Saskatchewan, Canada

$13{ }^{\mathrm{b}}$ Current address: Groupe de recherche interuniversitaire en limnologie (GRIL), Département des Sciences Biologiques, Université du Québec à Montréal, Montréal, Canada

${ }^{c}$ Department of Biology, York University, Toronto, Ontario, Canada

18 *Corresponding author: $\underline{\text { RichVogt@gmail.com }}$

19

22 Running head: Regulation of landscape-scale water quality 


\section{Abstract}

25 Aquatic ecosystems are subject to multiple interacting stressors that obscure regulatory

26 mechanisms and reduce the effectiveness of management strategies. Here we estimate the unique

27 and interactive effects of continental climate systems, regional meteorology, river hydrology, and

28 internal lake characteristics on patterns of landscape-scale water quality in six productive lakes

29 within a $52,000 \mathrm{~km}^{2}$ catchment. We quantify variation in mean summer and monthly algal

30 abundance, surface bloom intensity, water clarity, and density of potentially-toxic cyanobacteria

31 during 16 years on the Canadian Prairies. Internal lake characteristics best predicted overall

32 water quality change, while climate systems, regional weather, and river hydrology characterized

33 indirect pathways that influenced physico-chemical environments. Scenario analysis of future

34 environmental change predicted that atmospheric warming $\left(3-5^{\circ} \mathrm{C}\right)$ will have the strongest effect

35 on water quality in these productive lakes, but unexpectedly predicted that even severe industrial

36 water extraction (1\% of inflow) will have negligible effects on transparency or algal abundance.

37 Instead, nutrient management represents the only practical means to sustain water quality,

38 although atmospheric and lake warming may override re-oligotrophication of eutrophied sites in

39 future decades. 
Accurate prediction of the unique and interactive effects of climate and humans on

42 aquatic ecosystems will require an improved mechanistic understanding of how ecosystems

43 interact with and respond to environmental variability (Leavitt et al. 2009; Vogt et al. 2011).

44 Among the many challenges associated with such ecological forecasting is the mounting

45 evidence that threats to water quality (e.g., climate, nutrients, toxins, hydrologic flow, exotic

46 species) vary in space and time and can interact through complex pathways (Christensen et al.

47 2006; Palmer and Yan 2013). Development of effective management strategies to protect aquatic

48 ecosystems will require analytical frameworks suitable for large landscapes and that organize

49 anthropogenic and climatic stressors into hierarchies of threat (Brown et al. 2011) by identifying

50 the pathways by which environmental change degrades water quality. This need may be

51 particularly pronounced for lakes in central North America and other continental interiors where

52 dry conditions (Barrow 2009) combine with intensive agriculture (Hall et al. 1999; Bunting et al.

53 2016), urbanization (Leavitt et al. 2006; Waiser et al. 2010), and high climatic variability (Pham

54 et al. 2009; Pomeroy et al. 2007) to create multifaceted controls of water quality (Schindler and

55 Donahue 2006; Leavitt et al. 2009; Bunting et al. 2016).

Decades of research have shown that cultural eutrophication remains among the greatest

57 threats to sustainable water quality (Carpenter et al.1998; Schindler 2006). For example, lakes in

58 continental interiors often lie in large flat fertile agricultural catchments that deliver high nutrient

59 influx (Leavitt et al. 2006; Patoine et al. 2006) and characteristically exhibit high algal

60 productivity, low N:P ratios, and frequent blooms of nitrogen-fixing cyanobacteria (Haertel 1976;

61 Patoine et al. 2006; Orihel et al. 2012). Agricultural development is pervasive in these regions

$62(>75 \%$ of land area) such that eutrophication has been favoured by increased tillage, crop 
63 fertilization, and industrial livestock activities (Hall et al. 1999; Bunting et al. 2016). Similarly,

64 the low density and discharge of most regional rivers in dry interior regions (Bonsal and Shabbar

65 2008) can lead to disproportionate effects of nutrients and other contaminants from urban centres

66 (Leavitt et al. 2006; Waiser et al. 2010). Pollution of these phosphorus (P)-rich lakes with

67 nitrogen $(\mathrm{N})$ has been shown to increase production and toxicity of cyanobacteria by up to $500 \%$

68 (Leavitt et al. 2006; Donald et al. 2011; Orihel et al. 2012), with unambiguous evidence that

69 water quality has been degraded substantially by nutrients from agricultural and urban activities

70 during the past century (Hall et al. 1999; Maheaux et al. 2015; Bunting et al. 2016).

71 Climate variability has pronounced effects on lakes within continental interiors (Barrow

72 2009; Schindler and Donahue 2009). In the Canadian prairie region of the northern Great Plains,

73 climate variability arises from the interaction of three major climate systems and three air masses

74 (Arctic, Pacific, Gulf of Mexico) that supply moisture into the continental interior (Bonsal and

75 Shabbar 2008). The Pacific Decadal Oscillation (PDO) (Mantua et al. 1997) and El Niño-

76 Southern Oscillation (ENSO) (Trenberth and Hurrell 1994) both influence the influx of Pacific

77 precipitation to the Prairies and runoff from western mountains (St. Jacques et al. 2010; Shabbar

78 et al. 2011), with synergism among climate systems producing mild and arid conditions in winter

79 and spring (Mantua et al. 1997; McCabe et al. 2004; Bonsal et al. 2006), 10-fold variation in

80 spring runoff (Pomeroy et al. 2007), and up to 50-day variation in timing of plankton phenology

81 (McGowan et al. 2005; Dröscher et al. 2009). Similarly, the North Atlantic Oscillation (NAO;

82 computed using winter months) regulates annual cyclonic activity and winter breakouts of the

83 Arctic air mass into the Prairies (Hurrell 1995; Wang et al. 2006), timing of ice melt, and

84 development of the clear water phase during spring (McGowan et al. 2005; Dröscher et al. 2009).

85 Such strong climatic forcing is forecast to intensify in the future, with a $\sim 4^{\circ} \mathrm{C}$ increase in mean 
annual temperature of the Canadian Prairies by 2050 (Barrow 2009; Lapp et al. 2012; IPCC

87 2013), combining with lower snowfall and runoff (Cohen et al. 2015) to intensify both droughts and extreme pluvial periods (van der Kamp et al. 2008; Lapp et al. 2013). Together, these events

89 increase the variability of water chemistry (Pham et al. 2009), regional hydrology (Schindler and

90 Donahue 2006; Pomeroy et al. 2007), and energy budgets (Dröscher et al. 2009) resulting in

91 altered planktonic production, community composition, and cyanobacterial abundance (Huisman

92 et al. 2004; Paerl and Otten 2013).

93 Lakes in continental interiors may be further subjected to intensive hydrologic

94 management to regulate water supplies for urban, agricultural, and industrial applications

95 (Saskatchewan Water Security Agency, SWSA, 2013). For example, low elevation gradients

$96\left(\sim 0.4 \mathrm{~m} \mathrm{~km}^{-1}\right)$ and high precipitation deficits $\left(20-60 \mathrm{~cm} \mathrm{yr}^{-1}\right)$ (Pham et al. 2009), combine with

97 strongly seasonal precipitation (75\% during summer) and runoff mainly (75\% of annual

98 discharge) within a three-week interval during spring (Akinremi et al. 1999; Fang and Pomeroy

99 2007), to create low densities of small rivers through much of the northern Great Plains. In the

100 central Canadian Prairies, potash solution mines also alter regional hydrology by each consuming

101 up to $20 \times 10^{6} \mathrm{~m}^{3} \mathrm{yr}^{-1}$ of surface water at full production (J. Hovdebo, Director Licensing and

102 Water Use, SWSA, pers. comm.). When combined with similar magnitudes of urban and

103 agricultural uses, industrial applications could effectively eliminate flow in all but the largest

104 regional rivers (SWSA 2013). Although compensatory increases in water conveyance alleviate

105 shortfalls, perpetually augmented flows to offset year-round industrial water extraction can

106 favour vernal flooding and facilitate lotic transport of urban pollutants to downstream lakes

107 (Leavitt et al. 2006; Wyn et al. 2007). Given that these rivers also supply most of the potable

108 water to urban populations on the Canadian Prairies (Hall et al. 1999), an improved 
109 understanding of the effects of hydrologic regime on water quality is essential to developing

110 sustainable management strategies (Gober and Wheater 2014).

111 Here we use decadal time series from six productive lakes within the Canadian Prairies to

112 quantify the unique and shared effects of variation in continental climate systems, regional

113 meteorological conditions, hydrologic flow regimes, and internal lake characteristics on four

114 indices of regional water quality in eutrophic lakes: total algal abundance, incidence of algal

115 surface blooms, density of potentially-toxic cyanobacteria, and water clarity. We also outline an

116 analytical framework wherein we quantify how water quality parameters have changed over the

117 past 16 years, and apply a generalized numeric approach to determine which classes of predictors

118 have the greatest influence on prairie water quality. These empirical models are then used in a

119 scenario analysis to explore future water quality change in eutrophic hard water lakes in response

120 to expected climate warming, management of nutrients fluxes, and hydrologic modification.

121 Such models are needed to develop a roadmap for adaptive management of aquatic ecosystems,

122 while allowing for continued social and economic development.

\section{Methods}

Site Description - The six productive study lakes are situated within the Qu'Appelle

125 River catchment, a system that drains $\sim 52,000 \mathrm{~km}^{2}$ of mixed grassland in southern Saskatchewan

126 (SK), Canada (Fig. 1). This chain of lakes extends $\sim 400 \mathrm{~km}$ eastward from mesotrophic (Lake

127 Diefenbaker) and eutrophic reservoirs (Buffalo Pound) to hyper-eutrophic downstream lakes

128 (Katepwa, Crooked), with sub-saline Last Mountain Lake and hyper-eutrophic Wascana Lake

129 reservoir draining into the Qu'Appelle River through small tributaries near the City of Regina.

130 Regional climate is characterized as cool-summer humid continental (Köppen D $f b$ classification),

131 with short summers (mean $19^{\circ} \mathrm{C}$ in July), cold winters (mean $-16^{\circ} \mathrm{C}$ in January), and low annual 
132 temperatures $\left(\sim 1^{\circ} \mathrm{C}\right)$ with high seasonal variability. Average annual precipitation is $\sim 380 \mathrm{~mm}$,

133 with most rain falling between May and July, and most runoff occurs during a short snowmelt

134 period in spring (Akinremi et al. 1999; Fang and Pomeroy 2007). This region experiences high

135 hydrologic variability, such that river inflow to lakes varies by an order-of-magnitude between

136 years and across the catchment. The surrounding landscape is largely agricultural ( $75 \%$; grains

137 and pasture), with smaller sections remaining as undisturbed grassland ( 12\%) and surface

138 waters ( 5\%) (Hall et al. 1999; Finlay et al. 2015).

139 Study lakes are all productive, but vary up to 10-fold in most morphometric and

140 limnological parameters (Table 1; Supporting Information, SI, Table S1). Lakes are polymictic,

141 although Katepwa and Diefenbaker can exhibit limited thermal stratification during some

142 summers. Lakes share a common plankton composition distinguished by diverse summer

143 assemblages of cyanobacteria and abundant cyclopoid copepods (Patoine et al. 2006; Vogt et al.

144 2011). Regional fish communities include walleye (Sander vitreus), northern pike (Esox lucius),

145 yellow perch (Perca flavescens), cisco (Coregonus artedi), bigmouth buffalo (Ictiobus

146 cyprinellus), and white sucker (Catostomus commersoni), although precise community

147 composition and population densities are not known for most years.

148 Climate data - Time series of climate variables (1995-2010) were compiled from public

149 archives, including the US National Oceanic and Atmospheric Administration (North Atlantic

150 Oscillation index, NAO), the Australian National Climate Centre (Southern Oscillation Index,

151 SOI), and the University of Washington Joint Institute for the Study of the Atmosphere and

152 Ocean (PDO). Additionally, we estimated potential interactions between the PDO and El Niño

153 Southern Oscillation (ENSO; as SOI) as the product of the respective indices because low-flow

154 hydrological events are amplified by a synergistic interaction between El Niño phases of ENSO 
155 and positive phases of the PDO (Bonsal and Shabbar 2008; Shabbar and Yu 2012). The calendar

156 day of year (DOY) of spring ice melt 1995-2010 was obtained from Vogt et al. (2011).

Meteorology - Meteorological measurements (1995-2010) within the catchment were

158 obtained from the Environment Canada National Climate Archives

159 (http//www.climate.weatheroffice.gc.ca/ climateData) for four weather stations that occupy the

160 same latitudinal and longitudinal gradients as the study lakes (Fig. 1). Mean monthly air

161 temperature $\left({ }^{\circ} \mathrm{C}\right)$, precipitation $(\mathrm{mm})$, and daily wind speed $\left(\mathrm{km} \mathrm{h}^{-1}\right)$ were acquired for May-

162 August and were used to compute a mean summer value that overlapped with the limnological

163 sampling regimen (described below). Snow accumulation was estimated as the sum of monthly

164 precipitation from January-March in each calendar year. Variation in solar irradiance was

165 quantified by Environment Canada for each meteorological site (Vogt et al. 2011); however,

166 because of discontinuous data availability, energy fluxes could not be estimated for all lakes and

167 years, and irradiance data were not used in statistical models.

168 Hydrology - Hydrologic data were collected by the Saskatchewan Water Security Agency

169 (SWSA) and were assessed as the total monthly or summer inflow to each lake $\left(\mathrm{m}^{3} \mathrm{~d}^{-1}\right)$. Inflows

170 were estimated using flow gauges on streams, measurements of lake levels, and estimates of net

171 evaporation. Inflow data and lake volume were used to compute residence time for each lake and

172 year. In contrast, the nutrient content of river water was not available for most sites (c.f., Donald

173 et al. 2015), such that annual variation in allochthonous $\mathrm{N}$ and $\mathrm{P}$ influx could not be estimated for

174 all lakes and years, and were not included in statistical models. However, earlier mass balance

175 studies comparing the outflow of upstream lakes with the inflow of basins immediately

176 downstream (Patoine et al. 2006; Leavitt et al. 2006; Finlay et al. 2010) suggest that historical 
177 variations in water-column nutrient concentration (see below) can be used to approximate

178 historical changes in nutrient influx during the ice-free period.

Internal Lake Variables - Study lakes were sampled bi-weekly using standard protocols

180 from May to August during 1995-2010, except for Wascana Lake (1996-2010) (Patoine et al.

181 2006; Vogt et al. 2011). Depth-integrated samples were collected at midday at a standard geo-

182 positioned station in each lake by pooling casts of a 2-L Van Dorn water bottle taken every meter

183 to a maximum depth of $3 \mathrm{~m}$ (Buffalo Pound, Wascana), $6 \mathrm{~m}$ (Crooked), or $15 \mathrm{~m}$ (Diefenbaker,

184 Last Mountain, Katepwa). These integrated samples were filtered through a $0.45-\mu \mathrm{m}$ pore

185 membrane filter and analyzed at the University of Alberta Water Chemistry Laboratory for

186 concentrations of soluble reactive phosphorus (SRP, $\mu \mathrm{g} \mathrm{P} \mathrm{L}{ }^{-1}$ ) and total dissolved phosphorus

187 (TDP, $\mu \mathrm{g} \mathrm{P} \mathrm{L}^{-1}$ ), as well as total dissolved nitrogen (TDN), ammonium $\left(\mathrm{NH}_{4}^{+}\right.$), and the sum of

$188 \mathrm{NO}_{2}{ }^{2-}$ and $\mathrm{NO}_{3}{ }^{2-}\left(\right.$ all $\left.\mu \mathrm{g} \mathrm{N} \mathrm{L}^{-1}\right)$. Total inorganic (TIC) and dissolved organic carbon (DOC)

189 concentrations $\left(\mathrm{mg} \mathrm{C} \mathrm{L}^{-1}\right)$ in filtered samples were quantified using a Shimadzu model 5000A

190 (Shimadzu, Kyoto, Japan) total carbon analyzer following Finlay et al. (2009). Water

191 temperature $\left({ }^{\circ} \mathrm{C}\right.$; $\left.\mathrm{T}_{\text {water }}\right)$ and oxygen content $\left(\mathrm{mg} \mathrm{O}_{2} \mathrm{~L}^{-1}\right)$ were computed as average values of

192 depth profiles collected every $1 \mathrm{~m}$ using a YSI model 85 meter (YSI, Yellow Springs, Ohio,

193 USA), while $\mathrm{pH}$ was measured at the surface $(0.5 \mathrm{~m})$ using a calibrated handheld probe.

194 Zooplankton densities were estimated bi-weekly (May-August 1995-2010) from vertical

195 tows of a $20-\mathrm{cm}$ diameter Wisconsin net (243- $\mu \mathrm{m}$ mesh) at the standard sampling station in each

196 lake. Invertebrate samples were preserved and enumerated according to Patoine et al. (2006).

197 Densities of individual species (ind. $\mathrm{L}^{-1}$ ) were summed by month and for each year for a set of

198 taxonomic categories that included total zooplankton (all species), herbivorous or omnivorous

199 taxa (carnivores excluded), large-bodied cladocerans (Daphnia galeata mendotae, D. magna, D. 
pulex, Diaphanosoma birgei), small-bodied cladocerans (D. retrocurva, Bosmina longirostris,

201 Ceriodaphnia sp., Chydorus, sp.), and copepods (Leptodiaptomus siciloides, Diacyclops

202 thomasii). We anticipated that landscape-scale changes in planktivory by fish and invertebrates

203 (Vogt et al. 2013, 2015) would be evident as changes in the densities of large and small

204 zooplankton due to size-selective trophic interactions (Carpenter and Kitchell 1993).

Water Quality Indices - Water clarity was measured using a 20-cm diameter Secchi disk,

206 lowered in shade at a standard sampling station. Total algal abundance (total algae) was

207 estimated from depth-integrated water-column concentrations of chlorophyll $a(\mathrm{Chl} a)$, collected

208 from pooled Van Dorn samples taken at 1-m intervals, and quantified using standard trichromatic

209 techniques (Vogt et al. 2011). Surface chlorophyll $a$ (surface bloom intensity) was measured

210 similarly based on samples collected only in the uppermost $1 \mathrm{~m}$ of the water column.

211 Concentrations of colonial cyanobacteria were assessed based on the depth-integrated

212 concentrations of the taxonomically diagnostic carotenoid myxoxanthophyll, a biomarker for

213 colonial and potentially toxic cyanobacteria. Microscopic analysis shows that Microcystis and

214 Anabaena spp. are common phytoplankton in Qu'Appelle lakes, that these taxa produce

215 hepatotoxic microcystin (MC), and that toxin levels can exceed Canadian $\left(1.5 \mu \mathrm{g} \mathrm{L}^{-1}\right)$ and World

216 Health Organization $\left(1.0 \mu \mathrm{g} \mathrm{L}^{-1}\right)$ drinking water guidelines by 10-fold (Donald et al. 2011; Orihel

217 et al. 2012). Myxoxanthophyll concentration (nmoles L ${ }^{-1}$ ) was measured using an Agilent model

2181100 high performance liquid chromatography (HPLC) system (Agilent, Palo Alto, California,

219 USA) calibrated with authentic standards as described by Leavitt et al. (2006).

Data Analysis - Identification of hierarchical relationships among multiple environmental

221 stressors requires a diverse suite of statistical tools and a stepwise sequence of analytical

222 decisions (Sharma et al. 2008, 2013). Here we outline a general framework for such analysis that 
223 incorporates considerations of both temporal and spatial autocorrelation, model selection, and

224 variation-partitioning procedures, and which estimates the relative influence of diverse potential

225 regulators on environmental quality. We apply this three-step framework to the lake ecosystems

226 described above, but anticipate that our approach will be suitable for other ecosystems with long

227 time series.

228 In the first step, linear regression models were developed for both explanatory and

229 response variables to assess the mode of variation of each time series. For example, the

230 autocorrelation function (ACF) was used to quantify the series correlations in time series

231 residuals over a range of time lags (Carpenter 1993). In the presence of a significant linear trend,

232 time series were first detrended using first-difference procedures. In this paper, predictor and

233 response time series exhibited no statistically significant evidence of autocorrelations, thresholds,

234 discontinuities, nonlinearities, or oscillatory dynamics. As a result, there was no requirement for

235 subsequent models to include advanced time series procedures, such as autoregressive moving-

236 average components (Hampton et al. 2013).

237 In the second step, multiple regression models were developed independently for all water

238 quality indices using forward selection of predictors from the full suite of climatic,

239 meteorological, hydrological, and limnological variables (Sharma et al. 2013). As our goal was

240 to identify potential regulatory mechanisms, rather than develop the most parsimonious model,

241 final model composition was not based solely on Akaike's Information Criterion adjusted for

242 small sample sizes (AICc), although forward selection typically also produced the model with

243 lowest AICc (analysis not shown). Instead, we used a forward selection based on two-stopping

244 criteria to identify variables that would be included in the multiple regression model. Variables

245 were selected to be included in the model using significant alpha values less than 0.05 , and 
246 adjusted $\mathrm{R}^{2}$ values $\left(R_{a d j}^{2}\right)$ that significantly increased explained variation (Blanchet et al. 2008).

247 The relative contribution of each predictor was quantified using a type III sum of squares analysis

248 of variance (ANOVA) in which variation explained by each predictor was summed into classes

249 representing climate, meteorology, hydrology, and internal lake characteristics. In addition to the

250 four water quality indices, regression models were developed for their most influential predictors

251 ( $\mathrm{T}_{\text {water }}, \mathrm{SRP}, \mathrm{TIC}, \mathrm{pH}$; see below) to assess indirect controls of water quality. Initial analyses

252 focused on mean summer values, but data with monthly resolution were also used to quantify

253 seasonal differences in potential regulatory mechanisms. Preliminary correlation analysis

254 revealed that the only significant interaction between response variables was that of total algal

255 abundance and water clarity; hence it alone was included in the final models.

256 In all models, variables were transformed $\left(\log _{10}\right)$ as necessary to produce normal

257 distributions and multi-collinear parameters were excluded from final models (VIF>10, $\mathrm{r}>0.7)$.

258 Significant $(p<0.05)$ model parameters were selected using a Monte-Carlo forward selection

259 procedure with 9999 permutations (Blanchet et al. 2008) and model explanatory power was

260 summarized using adjusted coefficient of determination $\left(R_{\text {adj }}^{2}\right)$. The potential influence of

261 landscape position and site-specific, but un-measured, limnological variables on regression

262 models was estimated using a categorical lake identification code as a covariate; however, as lake

263 identity did not substantially influence model fit, this code was not retained in the final models

264 (analysis not shown). Similarly, time series were evaluated for the possibility of applying

265 regression tree analysis (Orihel et al. 2012), but this approach was not employed here because the

266 predictive power of such models was too low $\left(R^{2}<0.25\right)$, likely owing in part to the number of

267 sites and length of time series. All data manipulation and statistical analyses were performed in

268 the R-language environment (R Development Core Team 2013). 
In the third step, regression models were used to explore the effects of future scenarios of

270 regional environmental change on water quality and to identify potential management strategies.

271 Ensemble forecasts from general circulation models suggest that regional air temperatures will

272 increase $1.5-4^{\circ} \mathrm{C}$ by $2046-2065 \mathrm{CE}\left(5^{\circ} \mathrm{C}\right.$ by $\left.2100 \mathrm{CE}\right)$ (IPCC 2013$)$, while industrial water

273 extraction could nearly eliminate flow of all but the largest rivers if not augmented by

274 conveyance from headwater reservoirs (SWSA 2013). In addition, nutrient concentrations could

275 both decrease or increase in the near future, as regional runoff has declined $25 \%$ due to

276 diminished winter precipitation (Akinremi et al. 1999; St. Jacques et al. 2010) and the City of

277 Regina was required by Canadian federal law to upgrade wastewater facilities by 2017, but high

278 regional economic growth $\left(\sim 5 \%\right.$ year $\left.^{-1}\right)$ may increase non-point fluxes of nutrients. To forecast

279 how these factors may influence water quality, we applied the regression models to scenarios in

280 which we estimated values for total algae, surface blooms, and water clarity for a range of

281 potential increases in water temperature $\left(1-5^{\circ} \mathrm{C}\right)$, inflow regimes $(1 \%, 25 \%, 50 \%, 150 \%, 200 \%$,

282 and $1000 \%$ of current mean summer inflow), and nutrient fluxes $(10 \%, 25 \%, 50 \%, 200 \%$ and

$283300 \%$ of water column means). This scenario analysis included both the unique effects of each

284 stressor and factor interactions. Even though the multiple regression procedure generated a

285 statistically significant model abundances of colonial cyanobacteria, it was not included in this

286 forecast analysis because of its comparably weaker fit relative to the other water quality metrics

287 (see below).

\section{Results}

Time-series characteristics - There were no significant linear trends in mean summer

290 values for any of the four water quality parameters during 1995-2010 (Fig. 2, SI Table S2).

291 Similarly, time series showed no evidence of auto-correlation, despite an apparent 5-yr cycle in 
292 colonial cyanobacteria in the shallowest lakes (Wascana, Buffalo Pound). When analyzed with

293 data collected in May, total algal abundance $\left(R_{\text {adj }}^{2}=0.06, p=0.008\right)$, surface bloom intensity $\left(R_{\text {adj }}^{2}\right.$

$294=0.05, p=0.02)$, and densities of colonial cyanobacteria $\left(R_{\text {adj }}^{2}=0.04, p=0.04\right)$ all increased

295 slightly through time, whereas water transparency did not exhibit significant change (analysis not

296 shown). There were no significant temporal trends for any water quality variable for analyses

297 restricted to data from June, July, or August.

298 Among internal lake characteristics, only mean summer $\mathrm{pH}$ increased significantly $\left(R_{\text {adj }}^{2}\right.$

$299=0.28, p<0.0001$ ) during the 16-year sampling period (Finlay et al. 2009, 2015), although this

300 trend was statistically significant only during the months of May and July. Water temperature,

301 SRP, and TIC did not exhibit statistically significant trends in either summer or monthly mean

302 values. All limnological and environmental time series lacked significant temporal

303 autocorrelation over the period studied.

304 Models of summer water quality - Multiple regression models explained 26-75\% of

305 variation (as $R_{\text {adj }}^{2}$ ) in mean summer water quality parameters (Fig. 3a). In general, intrinsic

306 limnological characteristics were the strongest predictors of total algae, surface blooms, water

307 clarity, and abundance of colonial cyanobacteria, accounting for 53-80\% of explained variation.

308 River hydrology played a secondary role in predictive models, accounting for an additional 9-

$30925 \%$ of explained variation, while climate systems usually accounted for lower fractions of

310 explained variation in models of total algae $(\sim 11 \%)$, water clarity $(\sim 7 \%)$, and colonial

311 cyanobacteria ( 15\%). Regional meteorology was a substantial predictor for models of colonial

312 cyanobacterial abundance ( 33\% of explained variation) (Fig. 3a).

313 Total algal abundance and surface bloom intensity were both correlated positively with

314 changes in $\mathrm{T}_{\text {water, }} \mathrm{SRP}$, and $\mathrm{pH}$, and negatively with river inflow to lakes (SI Table S2). In 
315 addition, total algal abundance was related inversely to the NAO index. In contrast, water clarity

316 was correlated positively to lake inflow, TIC content, and PDOXENSO interactions, and

317 negatively to $\mathrm{T}_{\text {water }}$ and concentrations of Chl $a$ and SRP. Densities of colonial cyanobacteria

318 were correlated positively to $\mathrm{T}_{\text {water }}$ and negatively to wind speed and the ENSO (SI Table S2). In

319 all cases, model performance was equivalent when $\mathrm{NH}_{4}{ }^{+}$replaced SRP as a predictor (analysis

320 not shown), suggesting that the effects of these dissolved nutrients could not be distinguished.

321 Given the relative importance of select physico-chemical characteristics $\left(\mathrm{T}_{\text {water }}\right.$, dissolved

322 nutrients, TIC, $\mathrm{pH}$ ) as predictors of water quality, we built additional regression models to

323 investigate how these limnological parameters responded to variation in the climate systems,

324 regional meteorology, hydrological regimes, and other lake characteristics (Fig. 3b, SI Table S3).

325 These new models explained $23-51 \%\left(R_{\text {adj }}^{2}\right)$ of mean summer variation in limnological drivers of

326 water quality, with river hydrology ( $22-83 \%$ of explained variation), climate ( $20-76 \%)$, and

327 meteorological conditions ( 10-40\%) making important model contributions. Specifically, $\mathrm{T}_{\text {water }}$

328 was correlated positively to air temperature, but negatively to volume of inflow, ice-off date, and

329 snow accumulation, whereas SRP concentration was correlated negatively to river inflow and

330 wind speed, and TIC content was correlated positively to ice-off date and inversely to inflow

331 (Table 4). Only variation in mean summer $\mathrm{pH}$ was predicted by changes in other internal lake

332 characteristics ( $\sim 54 \%$ of explained variation) (Fig. 3b), with a positive correlation to water-

333 column DOC content, and a negative relationship with TIC concentration, NAO index, summer

334 precipitation, and date of ice melt.

335 Monthly models of water quality - Model performance varied substantially by month and

336 among water quality parameters (Fig. 4). For example, regression models based on data from

337 May explained $65-78 \%$ of variation in all water quality parameters except for colonial 
338 cyanobacteria, while more modest (26-70\%), but still statistically-significant, models could be

339 constructed for all parameters when models were based on data from July or August alone. In

340 contrast, only the models for water clarity and algal abundance were significant during June $\left(R_{\text {adj }}^{2}\right.$

$341=0.65, R_{\text {adj }}^{2}=0.30$ ). Similar to models of mean summer conditions, internal lake characteristics

342 exerted the greatest influence on monthly water quality, accounting for $80-100 \%$ of explained

343 variation during May-July and a reduced, but still paramount, proportion in August (Fig. 4).

344 Once again, $\mathrm{T}_{\text {water }}$, dissolved nutrients, TIC, and $\mathrm{pH}$ were the most important predictors of algal

345 abundance. Interestingly, river hydrology and regional meteorological conditions were correlated

346 with water-column Chl $a$ concentration, but not with the abundance of colonial cyanobacteria.

347 Overall, food-web processes were only significant in the water clarity models of May and June,

348 when large-bodied cladocerans were significant predictors of changes in secchi depth (15\% and

$3493 \%$ of explained variance, respectively).

$350 \quad$ Forecasting future water quality - Scenario analysis with regression models suggested

351 that increases in water temperature due to climate warming will have a greater effect on total

352 algal abundance and surface bloom intensity in these productive lakes than will either regional

353 management of nutrient sources or changes in hydrology resulting from industrial extraction or

354 compensatory increases in river conveyance (Table 2). For example, models predicted that total

355 algal abundance will increase by $\sim 75 \%$ with a $5^{\circ} \mathrm{C}$ increase in $\mathrm{T}_{\text {water, }}$, whereas $\mathrm{Chl} a$ content is

356 expected to vary little $( \pm 7 \%)$ if inflow is either doubled or declines to $1 \%$ of mean summer

357 inflow. Instead, algal abundance only declined appreciably ( 65\%) when hydrologic input to

358 lakes was increased $1000 \%$ over mean summer conditions, a value which exceeds conveyance

359 capacity of the Qu'Appelle River. Algal responses to changes in nutrient sources were of

360 intermediate intensity, with models predicting a $64 \%$ increase with three-fold higher 
361 concentrations, and a $29 \%$ decline if nutrient content was reduced to $10 \%$ of current mean

362 summer values. Similarly, the intensity of surface blooms increased progressively with $\mathrm{T}_{\text {water }}$

363 ( $\sim 60 \%$ for $5^{\circ} \mathrm{C}$ warming) and nutrients ( $\sim 50 \%$ for $300 \%$ increase), while a $200 \%$ change in mean

364 river flow altered such blooms by $<10 \%$. In contrast, water clarity is expected to change less

365 than $3 \%$ with even extreme atmospheric warming, 10-fold variation in nutrient content, or a

366 doubling of hydrologic inflow (Table 2). In all cases, interactions between temperature, nutrient,

367 and river flow scenarios were purely additive and there was no evidence of either synergistic or

368 antagonistic interactions when multiple parameters were manipulated.

370 Discussion

Analysis of 25 decadal time series demonstrated that water quality in eutrophic lakes of

372 the Canadian Prairies is regulated mainly by variation in internal lake characteristics (water

373 temperature, dissolved nutrients, pH) (Fig. 3a), but that these limnological parameters are

374 correlated in turn to variations in large-scale climate systems, regional meteorology, and river

375 hydrology (Fig. 3b). Unexpectedly, the composition of predictive models varied substantially

376 among closely related measures of phytoplankton communities (SI Table S2) and among months

377 (Fig. 4), underscoring the need to explicitly evaluate both direct and indirect pathways for each

378 ecological stressor and response parameter (Palmer and Yan 2013). Further, application of these

379 models to realistic scenarios of future environmental change (Table 2) showed that potential

380 regulatory mechanisms with the greatest effect on water quality (temperature increase) or the

381 greatest ease of management (1000\% variation in river conveyance) did not represent the most

382 effective means of sustaining regional water quality in the coming decades (nutrient diversion).

383 Such quantitative assessment of the relative effects of multiple forcing mechanisms is important 
384 to allow scientists and managers to develop effective and adaptive management strategies to

385 protect aquatic resources (Schindler 2001; Gober and Wheater 2014).

Controls of summer water quality - Regression analysis suggested that water quality

387 change during the past two decades was explained best by variation in $\mathrm{T}_{\text {water }}$, solute content, and

388 inflow regimes, factors that were ultimately under climatic control (SI Table S2). Elevated $\mathrm{T}_{\text {water }}$

389 increases algal growth (Paerl and Otten 2013; Winder and Sommer 2012) and intensifies the

390 thermal stratification that favours buoyancy-regulating, bloom-forming cyanobacteria in

391 eutrophic lakes (Huisman et al. 2004; Cantin et al. 2011). Warmer surface waters arise from

392 changes in the net energy budget of a lake (e.g., MacIntyre et al. 2014), which, for polymictic

393 prairie lakes, is mainly due to altered transmission of solar irradiance (O'Reilley et al. 2015),

394 variation in air mass and its temperature (Bonsal et al. 2006; Bonsal and Shabbar 2008), and

395 influx of discrete water sources (Dröscher et al. 2009). Although direct irradiance measures were

396 not available for all lakes and years as required for regression model analysis, previous analysis

397 of data from six regional meteorological stations (Vogt et al. 2011) reveals a slow increase in

398 regional receipt of solar energy and extremely low interannual variation (coefficient of variation

$399=6 \%$ ), in contrast to stable but more annually-variable lake parameters (Fig. 2). As well, earlier

400 analysis of energy budgets for regional lakes reveals that interannual variation in the rate of

401 summer heat accumulation in lakes ( $\sim 50$ days) is controlled by interactions between the mass of

402 snow received the preceding winter, timing of spring ice melt, and the volume of cold-water

403 runoff during the vernal freshet (Dröscher et al. 2009), all of which were identified as important

404 predictors in our regression analysis (SI Table S3). Spring runoff also influences algal density by

405 altering water renewal rates (dilution) in central North American lakes, as $\sim 75 \%$ of regional river

406 discharge occurs during 3 weeks of March-April, yet runoff volume varies by 10 -fold among 
years (Fang and Pomeroy 2007; Pham et al. 2009). The importance of interannual variation in

408 seasonal properties is underlined by the fact that regression models explained up to $75 \%$ of

409 interannual variation in water quality parameters, despite the fact that there were no linear or

410 discontinuous changes in mean summer algal abundance, bloom characteristics, or water clarity

411 (Fig. 2).

412 Identification of separate influences of climate systems and regional meteorology on

413 water quality in eutrophic ecosystems is consistent with mechanisms known to regulate

414 atmospheric conditions in central Canada. Regional warming occurs most commonly when El

415 Niño and positive-phase PDO events interact to increase sea surface temperatures in the eastern

416 North Pacific Ocean and force jet-stream position northward beyond the Prairies (Shabbar et al.

417 2011). Similarly, introduction of synoptic precipitation into central Canada is influenced by the

418 position of continental jet streams that variously import water from the northern Pacific Ocean,

419 the Gulf of California, and the Gulf of Mexico (Higgins et al. 1997; Liu and Stewart 2003).

420 Finally, timing of ice melt is influenced strongly by atmospheric teleconnections, as warm spring

421 conditions are common during synergistic interactions between El Niño events and the PDO

422 (Bonsal et al. 2006), while winter extreme temperatures and ice cover are influenced by changes

423 in atmospheric circulation in the Arctic (as NAO) (Dröscher et al. 2009). Thus, while regional air

424 and water temperatures vary synchronously as a result of seasonal cycles of solar irradiance and

425 direct water-column heating, interactions among climate systems provide additional indirect

426 controls of lake warming through hydrologic variability (Dröscher et al. 2009).

427 Interactions between river hydrology, nutrient status, and lake production revealed by

428 regression models (SI Tables S2, S3) are consistent with regulatory mechanisms identified by

429 decadal-scale macronutrient budgets (Patoine et al. 2006; Leavitt et al. 2006; Finlay et al. 2010). 
430 For example, regression models suggest that algal abundance is stimulated by nutrient content,

431 but reduced by river inflow (Table 2), despite allochthonous nutrient influx being a ubiquitous

432 predictor of lentic Chl content (Schindler 2006). Analysis of mass-balance budgets reconciles

433 these observations by demonstrating that lake sediments presently account for up to $85 \%$ of

434 nutrient supply to the water column of these eutrophic lakes (Patoine et al. 2006). In addition,

435 cold-region hydrological models (Pomeroy et al. 2007) and stable isotope analyses (Pham et al.

436 2009) both reveal that the brief snow melt in spring is the predominant source of water to

437 regional rivers and lakes and that the volume of runoff is greatest when rapid snow melt occurs

438 over frozen soils, conditions that favour water, but not necessarily nutrient, mobilization. As

439 well, we note that flow in the Qu'Appelle River is subject to engineered conveyance from

440 upstream lakes and that such channelized flow can decouple the relationships between climate,

441 runoff, and lotic nutrient concentrations seen elsewhere (McCullough et al. 2012; Bunting et al.

442 2016). Thus, while it remains necessary to be cautious about inference of regulatory mechanisms

443 from a regression-based analysis, the strong support of our models by whole-lake mass balance

444 budgets, catchment-scale nutrient transport studies, and centennial-scale paleoecological research

445 provides a solid mechanistic basis for our findings and their application to eutrophic lakes.

446 Comparison of regression model composition (SI Table S2) suggests that regulatory

447 pathways may differ substantially among even highly correlated water quality parameters or

448 limnological characteristics (Fig. 5). For example, models of total algal abundance and water

449 clarity were complex, of similar predictive power, and influenced by combination of climate

450 systems, hydrologic characteristics, and limnological properties, as described above. In contrast,

451 the model for colonial cyanobacteria included only variables related to energetic characteristics

452 of lakes (temperature, wind speed, ENSO), a combination of variables that is consistent with 
453 other research showing that colonial cyanobacteria are most abundant in eutrophic sites during

454 years when waters are warm, wind speed is low, and lakes exhibit stronger thermal stratification

455 (Huisman et al. 2004; Zhang et al. 2012; Paerl and Otten 2013). All these conditions are

456 enhanced during El Niño events and, accordingly, we note that both shallow lakes (Wascana,

457 Buffalo Pound) exhibited $~ 5$ year cycles of colonial cyanobacteria abundance (Fig. 2) which,

458 while not statistically significant, peaked during known El Niño events (e.g., 1997). Such

459 marked differences among predictive models are important to document, as they suggest that

460 eutrophic lake management strategies will vary according to the precise regulatory goal (e.g.,

461 increased transparency, reduced cyanobacteria).

Seasonal variation in predictive models - Pronounced variation in the predictive power of

463 water-quality models developed with monthly data (Fig. 4) is consistent with known patterns of

464 plankton phenology in the Qu'Appelle catchment. For example, algal abundance and water

465 clarity models were strong in May $\left(R_{\text {adj }}^{2}>0.65\right)$ when phytoplankton communities are composed

466 of diatoms and flagellates and complete water-column mixing eliminates vertical zonation of

467 phytoplankton (McGowan et al. 2005; Vogt et al. 2011). In contrast, colonial cyanobacteria are

468 rare in Qu'Appelle lakes during spring (Patoine et al. 2006), consistent with non-significant

469 model for their characteristic biomarker, myxoxanthophyll, during May. Overall, statistical

470 models suggested a role of herbivory in regulating water quality in early summer (but not all

471 summer), with the inclusion of large-bodied herbivores as predictors of water clarity in May and

472 June, the months in which intense grazing by large-bodied Daphnia spp. reduces algal biomass

473 and increases Secchi depth by up to 10-fold (Dröscher et al. 2009). In addition, while all water

474 quality models were significant when developed with data from either July or August, the latter

475 models were uniformly more predictive than those based on July data, possibly reflecting the fact 
476 that the high thermal capacity of very large lakes can extend cooler waters and clear water phases

477 later into the summer (Dröscher et al. 2009). Instead, parameters related closely to elevated

478 temperatures played a more important role in regression models developed with data from August 479 (Fig. 4d).

Landscape management of lakes - The analytical framework employed here allows us to

481 differentiate among global climate systems, regional meteorology, river hydrology, and site482 specific limnological features as potential controls of water quality in productive lakes at the 483 landscape scale. Although our models were based solely on linear regression analysis, this 484 simple approach was warranted by the data structure, and more complicated analytical 485 approaches were unnecessary (e.g., detrending, regression trees, multivariate autoregressive 486 models, spectral analysis) (Hampton et al. 2013). Regardless, our analysis explained on average $487 \sim 50 \%$ of observed interannual variation in algal abundance (SI Table S2), despite the absence of 488 any progressive trend in lake production during the past two decades (Fig. 2). Instead, 489 application of these models allowed us to develop a roadmap for adaptive management of 490 continental lakes in the face of future warming of $1.5-5^{\circ} \mathrm{C}$ (IPCC 2013), nutrient pollution from 491 farms and cities (Leavitt et al. 2006; Bunting et al. 2016), and industrial extraction of water by 492 agriculture or solute mines (SWSA 2013). Analysis of model forecasts suggests that resource managers in semi-arid agricultural 494 regions will have few options to improve regional water quality through regulation of energy and 495 water fluxes. For example, while water temperatures were the best predictor of algal production 496 (Table 2), direct reduction of energy influx to lakes is not possible. Similarly, the effectiveness 497 of indirect management of thermal properties by cold water runoff is likely to be limited to early 498 summer (Dröscher et al. 2009) due to high seasonality of discharge (Pomeroy et al. 2007; Fang 
and Pomeroy 2007) and long hydrological transit times among lakes (Fig. 1). In addition,

500 although water conveyance though the Qu'Appelle River has been managed for over a century

501 via reservoirs (Diefenbaker, Buffalo Pound, Wascana) and outlet dams on natural lakes (Hall et

502 al. 1999; SWSA 2013), the limited channel capacity and low topographic relief $\left(0.4 \mathrm{~m} \mathrm{~km}^{-1}\right)$

503 greatly constrains river discharge unless accompanied by re-channelization of the river. Even so,

504 our analysis shows that more than a doubling of lotic conveyance will have negligible effects

$505(<5 \%)$ on water quality (Table 2$)$, a pattern which may generalize well to other dry continental

506 regions. In fact, even unrealistically diminished river flow (1\% of mean summer values) appears

507 to have only relatively minor effects ( $<10 \%$ reduction) on water quality (Table 2$)$. Further

508 analysis of the independent influx of nutrients and water from discrete sources (livestock

509 operations, cities, crop production) will help refine this observation (Bunting et al. 2016).

510 Application of regression models to realistic scenarios suggests that reductions in nutrient

511 influx may be the most practical means of preserving regional water quality in the immediate

512 future. Consistent with this prediction, previous research shows that algal abundance in

513 eutrophic Qu'Appelle lakes has increased up to $300 \%$, and cyanobacteria by $>500 \%$, as a linear

514 function $\left(r^{2}>0.70, p<0.05\right)$ of the influx of dissolved $\mathrm{N}$ (mainly $\mathrm{NH}_{4}{ }^{+}$) from urban centres during

515 1900-1980 (Hall et al. 1999; Leavitt et al. 2006, 2009). Presently, urban point sources represent

$516 \sim 70 \%$ of total ecosystem $\mathrm{N}$ in downstream lakes (Leavitt et al. 2006); however, wastewater

517 treatment plants are mandated by federal legislation to reduce $\mathrm{NH}_{4}{ }^{+}$pollution to $\sim 15 \%$ of current

518 discharge by 2017, and are already operational in the City of Regina. Because fertilization with

$519 \mathrm{NH}_{4}{ }^{+}$increases algal bloom density and toxicity by up to $400 \%$ in these SRP-rich lakes (reviewed

520 in Donald et al. 2011), substantial diversion of $\mathrm{N}$ is expected to improve water quality.

521 Interestingly, our models forecast less improvement in water quality (Table 2) than would be 
522 expected on the basis of paleolimnological, mass-balance, and experimental studies (Hall et al.

523 1999; Leavitt et al. 2006; Donald et al. 2011), possibly because our regression-based approach

524 cannot estimate centennial-scale changes in nutrient regimes, sedimentary sources may reduce

525 lake sensitivity to allochthonous nutrient influx (Jeppesen et al. 2005; Patoine et al. 2006), or

526 because some Qu'Appelle lakes are not impacted by urban wastewater (Leavitt et al. 2006).

527 Regulatory mechanisms and management strategies indentified here should generalize

528 well to continental landscapes with similar climatic, edaphic, and limnological characteristics.

529 Long-term changes in carbon fluxes (Finlay et al. 2010, 2015), nitrogen biogeochemistry (Bogard

530 et al. 2012), water sources (Pham et al. 2009), and climatic forcing (Pham et al. 2009, Vogt et al.

5312011 ) are highly synchronous among Qu'Appelle and other lakes within a 235,000 $\mathrm{km}^{2}$ prairie

532 region, irrespective of basin hydrology (open or closed drainage). Although less well studied

533 than boreal regions, such continental interiors account for $\sim 8,000,000 \mathrm{~km}^{2}$ (Finlay et al. 2015)

534 and their freshwaters are critical resources for social and economic development (Barica 1987;

535 Schindler 2001) as well as regulation of climatic processes (Finlay et al. 2015). The models

536 presented here represent an important first step in establishing a predictive understanding of

537 relative importance of environmental and human mechanisms threatening lakes in these districts

538 (Brown et al. 2011). Collectively, the analyses presented here suggest that regional management

539 of continental lakes should focus on nutrient regulation as a means of mitigating cultural

540 eutrophication, but caution that improvements on the decadal scale may be offset by continued

541 climate warming (Table 2).

542

543

544 


\section{Acknowledgements}

546 We thank members of the Limnology Laboratory for assistance with data collection since

547 1994, Curtis Halborg, and Bart Oegema at the Saskatchewan Water Security Agency for

548 estimates of river flow, and Daniel Schindler, Kerri Finlay, James Rusak, Gavin Simpson, Björn

549 Wissel, Matthew Bogard, and Heather Haig for insightful comments that improved the

550 manuscript. This paper was also improved by critiques from G.W. Kling and two anonymous

551 reviewers. This work was supported by the Natural Sciences and Engineering Research Council

552 of Canada Discovery Grants, the Canada Research Chair Program, Canada Foundation for

553 Innovation, the Province of Saskatchewan, the University of Regina, Nature Regina, York

554 University, and Université du Québec à Montréal.

555 


\section{References}

557 Akinremi, O. O., S. M. McGinn, and H. W. Cutforth. 1999. Precipitation trends on the Canadian $558 \quad$ Prairies. J. Climate 12: 2996-3003.

559 Barica, J. 1987. Water quality problems associated with productivity of prairie lakes in Canada: $560 \quad$ A review. Water Qual. Bull. 12: 107-115.

561 Barrow, E. 2009. Climate scenarios for Saskatchewan. Prairie Adaptation Research

562 Collaborative Report. University of Regina, Regina, Saskatchewan, Canada. 131 pp.

563 Blanchet, F. G., P. Legendre, and D. Borcard. 2008. Forward selection of explanatory variables.

$564 \quad$ Ecology 89: 2623-2632.

565 Bogard, M. J., D. B. Donald, K. Finlay, and P. R. Leavitt. 2012. Distribution and regulation of

566 urea in lakes of central North America. Freshwat. Biol. 57: 1277-1292.

567 Bonsal, B. R., T. D. Prowse, C. R. Duguay, and M. P. Lacroix. 2006. Impacts of large-scale

568 teleconnections on freshwater-ice break/freeze-up dates over Canada. J. Hydrol. 330: 340-

569353.

570 Bonsal, B., and A. Shabbar. 2008. Impacts of large-scale circulation variability on low

$571 \quad$ streamflows over Canada: A review. Can. Water Res. J. 33: 137-154.

572 Brown, C. J., and others. 2011. Quantitative approaches in climate change ecology. Global

$573 \quad$ Change Biol. 17: 3697-3713.

574 Bunting, L., and others. 2016. Increased variability and sudden ecosystem state change in Lake

575 Winnipeg, Canada, caused by 20th century agriculture. Limnol. Oceanogr. 61: In press.

576 Cantin, A., B. E. Beisner, J. M. Gunn, Y. T. Prairie, and J. G. Winter. 2011. Effects of

577 thermocline deepening on lake plankton communities. Can. J. Fish. Aquat. Sci. 68: 260-276.

578 Carpenter, S. R. 1993. Statistical analysis of the ecosystem experiments, p. 26-42. In S. R. 
Carpenter and J. F. Kitchell [eds.], The trophic cascade in lakes. Cambridge.

580 Carpenter, S. R., and J. F. Kitchell. 1993. The Trophic Cascade in Lakes. Cambridge University

$581 \quad$ Press. 385 pp.

582 Carpenter, S. R., and others. 1998. Nonpoint pollution of surface waters with phosphorus and $583 \quad$ nitrogen. Ecol. Applic. 8: 559-568.

584 Christensen, M. R., and others. 2006. Multiple anthropogenic stressors cause ecological surprises 585 in boreal lakes. Global Change Biol. 12: 2316-2322.

586 Cohen, S., G. Koshida, and L. Mortsch. 2015. Climate and water availability indicators in 587 Canada: Challenges and a way forward. Part III- Future scenarios. Can. Water Resourc. J. $588 \quad$ 40: $160-172$.

589 Donald, D. B., M. J. Bogard, K. Finlay, and P. R. Leavitt. 2011. Comparative effects of urea, 590 ammonium, and nitrate on phytoplankton abundance, community composition, and toxicity 591 in hypereutrophic freshwaters. Limnol. Oceanogr. 56: 2161-2175.

592 Donald, D. B., B. R. Parker, J.-M. Davies, and P. R. Leavitt. 2015. Nutrient sequestration in the 593 Lake Winnipeg watershed. J. Great Lakes Res. 41: 630-642.

594 Dröscher, I., A. Patoine, K. Finlay, and P. R. Leavitt. 2009. Climate control of the spring clear595 water phase through the transfer of energy and mass to lakes. Limnol. Oceanogr. 54: 24695962480.

597 Fang, X., and J. W. Pomeroy. 2007. Snowmelt runoff sensitivity analysis to drought on the $598 \quad$ Canadian prairies. Hydrol. Process. 21: 2594-2609.

599 Finlay, K., P. R. Leavitt, B. Wissel, and Y. T. Prairie. 2009. Regulation of spatial and temporal 600 variability of carbon flux in six hard-water lakes of the northern Great Plains. Limnol.

$601 \quad$ Oceanogr. 54: 2553-2564. 
602 Finlay, K., P. R. Leavitt, A. Patoine, and B. Wissel. 2010. Magnitudes and controls of organic

603 and inorganic carbon flux through a chain of hard-water lakes on the northern Great Plains.

604 Limnol. Oceanogr. 55: 1551-1564.

605 Finlay, K., and others. 2015. Decrease in $\mathrm{CO}_{2}$ efflux from northern hardwater lakes with

606 increasing atmospheric warming. Nature 519: 215-218.

607 Gober, P., and H. S. Wheater. 2014. Socio-hydrology and the science-policy interface: a case

608 study of the Saskatchewan River basin. Hydrol. Earth Syst. Sci. 18: 1413-1422.

609 Haertel, L. 1976. Nutrient limitation of algal standing crops in shallow prairie lakes. Ecology 57:

$610 \quad 664-678$.

611 Hall, R. I., P. R. Leavitt, R. Quinlan, A. S. Dixit, and J. P. Smol. 1999. Effects of agriculture,

612 urbanization, and climate on water quality in the northern Great Plains. Limnol. Oceanogr.

$613 \quad 44: 739-756$.

614 Hampton, S. E., and others. 2013. Quantifying effects of abiotic and biotic drivers on community

615 dynamics with multivariate autoregressive (MAR) models. Ecology 94: 2663-2669.

616 Higgins, R. W., Y. Yao, E. S. Yarosh, J. E. Janowiak, and K. C. Mo. 1997. Influence of the Great

617 Plains Low-Level Jet on summertime precipitation and moisture transport over the Central

$618 \quad$ United States. J. Climate 10: 481-507.

619 Huisman, J., and others. 2004. Changes in turbulent mixing shift competition for light between

620 phytoplankton species. Ecology 85: 2960-2970.

621 Hurrell, J. W. 1995. Decadal trends in the North-Atlantic Oscillation - regional temperatures and

622 precipitation. Science 269: 676-679.

623 Intergovernmental Panel on Climate Change [IPCC]. 2013. Climate Change 2013: The Physical

624 Science Basis. Contribution of Working Group I to the Fifth Assessment Report of the 
625 Intergovernmental Panel on Climate Change, Stocker, T. F., and others (eds.). Cambridge

626 University Press, 1535 pp.

627 Jeppesen, E., and others. 2005. Lake responses to reduce nutrient loading - An analysis of 628 contemporary long-term data from 35 case studies. Freshwat. Biol. 50: 1747-1771.

629 Lapp, S. L. J. M. St. Jacques, E. Barrow, and D. J. Sauchyn. 2012. GCM projections for the 630 Pacific Decadal Oscillation under greenhouse forcing for the early $21^{\text {st }}$ century. Internat. J. $631 \quad$ Climatol. 32: 1423-1442.

632 Lapp, S. L. J. M. St. Jacques, D. J. Sauchyn, and J. R. Vanstone. 2013. Forcing of hydrologic 633 variability in the northwestern Great Plains since AD1406. Quatern. Internat. 310: 47-61.

634 Leavitt, P. R., C. S. Brock, C. Ebel, and A. Patoine. 2006. Landscape-scale effects of urban 635 nitrogen on a chain of freshwater lakes in central North America. Limnol. Oceanogr. 51: $636 \quad 2262-2277$.

637 Leavitt, P. R., and others. 2009. Paleolimnological evidence of the effects on lakes of energy and 638 mass transfer from climate and humans. Limnol, Oceanogr. 54: 2330-2348.

639 Liu, J., and R. E. Stewart. 2003. Water vapor fluxes over the Saskatchewan River Basin. J. $640 \quad$ Hydrometeorol. 4: 944-959.

641 MacIntyre, S., J. R. Romero, G. M. Silsbe, and B. M. Emery. 2014. Stratification and horizontal 642 exchange in Lake Victoria, East Africa. Limnol. Oceanogr. 59: 1805-1838.

643 Maheaux, H., P. R. Leavitt, and L. J. Jackson. 2016. Asynchronous onset of eutrophication 644 among shallow prairie lakes of the northern Great Plains, Alberta, Canada. Global Change 645 Biol. 22: 271-283.

646 Mantua, M. J., S. Hare, Y. Zhang, J. M. Wallace, and R. C. Francis. 1997. A Pacific interdecadal 647 climate oscillation with impacts on salmon production. Bull. Am. Meteorol. Soc. 78: 1069- 
649 McCabe, G. J., M. A. Palecki, and J. L. Betancourt. 2004. Pacific and Atlantic Ocean influences

650 on multidecadal drought frequency in the United States. Proc. Natl. Acad. Sci. USA 101:

$651 \quad 4136-4141$.

652 McCullough, G. K., and others. 2012. Hydrological forcing of a recent trophic surge in Lake 653 Winnipeg. J. Great Lakes Res. 38 (Suppl. 3): 95-105.

654 McGowan, S., A. Patoine, M. D. Graham, and P. R. Leavitt. 2005. Intrinsic and extrinsic 655 controls of lake phytoplankton synchrony. Verh. Internat. Verein Limnol. 29: 794-798.

656 O'Reilly, C. M. and others. 2015. Rapid and highly variable warming of lake surface waters 657 around the globe. Geophys. Res. Lett. 42: 10773-10781.

658 Orihel, D. M., and others. 2012. High microcystin concentrations occur only at low nitrogen-to659 phosphorus ratios in nutrient-rich Canadian lakes. Can. J. Fish. Aquat. Sci. 69: 1457-1462.

660 Paerl, H. W., and T. G. Otten. 2013. Harmful cyanobacterial blooms: Causes, consequences, and $661 \quad$ controls. Microb. Ecol. 65: 995-1010.

662 Palmer, M. E., and N. D. Yan. 2013. Decadal-scale regional changes in Canadian freshwater 663 zooplankton: The likely consequence of complex interactions among multiple anthropogenic $664 \quad$ stressors. Freshwat. Biol. 58: 1366-1378.

665 Patoine, A., M. D. Graham, and P. R. Leavitt. 2006. Spatial variation of nitrogen fixation in lakes 666 of the northern Great Plains. Limnol. Oceanogr. 51: 1665-1677.

667 Pham, S. V., P. R. Leavitt, S. McGowan, and P. Peres-Neto. 2008. Spatial variability of climate 668 and land-use effects on lakes of the northern Great Plains. Limnol. Oceanogr. 53: 728-742.

669 Pham, S. V., P. R. Leavitt, S. McGowan, B. Wissel, and L. Wassenaar. 2009. Spatial and 670 temporal variability of prairie lake hydrology as revealed using stable isotopes of hydrogen 
and oxygen. Limnol. Oceanogr. 54: 101-118.

672 Pomeroy, J. W., and others. 2007. The cold regions hydrological model: A platform for basing

673 process representation and model structure on physical evidence. Hydrol. Process. 21: 26506742667.

675 R Development Core Team. 2013. R: A language and environment for statistical computing. R 676 Foundation for Statistical Computing, Austria.

677 Saskatchewan Water Security Agency (SWSA). 2013. 25 Year Water Security Plan.

678 Saskatchewan Water Security Agency, Moose Jaw, Saskatchewan. 53 pp.

679 https://www.wsask.ca/Global/About\%20WSA/25\%20Year\%20Water\%20Security\%20Plan/

$680 \quad$ WSA 25YearReportweb.pdf

681 Schindler, D. W. 2001. The cumulative effects of climate warming and other human stresses on

682 Canadian freshwaters in the new millennium. Can. J. Fish. Aquat. Sci. 58: 18-29.

683 DOI:10.1139/cjfas-58-1-18.

684 Schindler, D. W. 2006. Recent advances in the understanding and management of eutrophication.

685 Limnol. Oceanogr. 51: 356-363.

686 Schindler, D. W., and W. F. Donahue. 2006. An impending water crisis in Canada's western

687 prairie provinces. Proc. Nat. Acad. Sci. USA 103: 7210-7216.

688 Shabbar, A., and B. Yu. 2012. Intraseasonal Canadian winter temperature responses to

689 interannual and interdecadal Pacific SST modulations. Atmosphere-Ocean 50: 109-121.

690 Shabbar, A., B. R. Bonsal, and K. Szeto. 2011. Atmospheric and oceanic variability associated

691 with growing season droughts and pluvials on the Canadian Prairies. Atmosphere-Ocean 49:

$692 \quad 339-355$.

693 Sharma, S., J. J. Magnuson, G. Mendoza, and S. R Carpenter. 2013. Influences of local weather, 

large-scale climatic drivers, and the ca. 11 year solar cycle on lake ice breakup dates; 19052004. Climatic Change 118: 857-870.

696 Sharma, S., S. Walker, and D. A. Jackson. 2008. Empirical modelling of lake water relationships: 697 A comparison of predictive modelling approaches. Freshwat. Biol. 53: 897-911.

698 St. Jacques, J. M., D. J. Sauchyn, and Y. Zhao. 2010. Northern Rocky Mountain streamflow 699 records: Global warming trends, human impacts or natural variability? Geophys. Res. Lett. $700 \quad 37:$ L06407.

701 Trenberth, K.E., and J. W. Hurrell. 1994. Decadal atmospheric-ocean variations in the Pacific. 702 Clim. Dyn. 9: 303-319.

703 Van der Kamp, G., D. Keir, and M. Evans. 2008. Long-term water level changes in closed-basin 704 lakes of the Canadian Prairies. Can. Wat. Res. J. 33: 23-28.

705 Vogt R. J., J. A. Rusak, A. Patoine, and P. R. Leavitt. 2011. Differential effects of energy and mass influx on the landscape synchrony of lake ecosystems. Ecology 92: 1104-1114.

707 Vogt, R. J., B. Matthews, T. P. Cobb, M. D. Graham, and P. R. Leavitt. 2013. Food web 708 consequences of size-based predation and vertical migration of an invertebrate predator 709 (Leptodora kindtii). Limnol. Oceanogr. 58: 1790-1801. doi:10.4319/lo.2013.58.5.1790.

710 Vogt, R. J., S. Sharma, and P. R. Leavitt. 2015. Decadal regulation of phytoplankton abundance 711 and water clarity in a large continental reservoir by climatic, hydrologic and trophic 712 processes. J. Great Lakes Res. 41: 81-90.

713 Waiser, M. J., V. Tumber, and J. Holm. 2010. Effluence-dominated streams. Part 1. Presence 714 and effects of excess nitrogen and phosphorus in Wascana Creek, Saskatchewan, Canada. 715 Environ. Toxicol. Chem. 30: 496-507.

716 Wang, X. L., H. Wan, and V. R. Swail. 2006. Observed changes in cyclone activity in Canada 
717 and their relationships to major circulation regimes. J. Climate. 19: 896-915.

718 Winder, M., and U. Sommer. 2012. Phytoplankton response to a changing climate.

719 Hydrobiologia 698: 5-16.

720 Wyn, B., J. N. Sweetman, P. R. Leavitt, D. B. Donald. 2007. Historical metal concentrations in 721 lacustrine food webs revealed using fossil ephippia from Daphnia. Ecol. Applic. 17: 754722764.

723 Zhang, M., H. Duan, X. Shi, Y. Yu, and F. Kong. 2012. Contributions of meteorology to the 724 phenology of cyanobacterial blooms: Implications for future climate change. Water Res. 46:

$725 \quad 442-452$.


Table 1. Morphometric characteristics of study lakes are listed for the Qu'Appelle River catchment, Saskatchewan, Canada.

\begin{tabular}{lcccccc}
\hline & Buffalo Pound & Crooked & Diefenbaker & Katepwa & Last Mountain & Wascana \\
\hline Latitude $\left({ }^{\circ} \mathrm{N}\right)$-Longitude $\left({ }^{\circ} \mathrm{W}\right)$ & $50.65-105.50$ & $50.6-102.73$ & $51.12-106.63$ & $50.7-103.65$ & $51.08-105.23$ & $50.45-104.61$ \\
Elevation $(\mathrm{m})$ & 509.30 & 451.70 & 552.00 & 478.20 & 490.10 & 570.50 \\
Lake Area $\left(\mathrm{km}^{2}\right)$ & 29.10 & 15.00 & 500.00 & 16.20 & 226.60 & 0.50 \\
Mean Depth $(\mathrm{m})$ & 3.00 & 8.06 & 33.00 & 14.30 & 7.90 & 1.50 \\
Max Depth $(\mathrm{m})$ & 5.50 & 16.50 & 62.00 & 23.20 & 30.80 & 3.00 \\
Volume $\left(\mathrm{m}^{3}\right)$ & $8.75 \times 10^{7}$ & $1.21 \times 10^{8}$ & $9.40 \times 10^{9}$ & $2.33 \times 10^{8}$ & $1.81 \times 10^{9}$ & $7.00 \times 10^{5}$ \\
Water Residence Time $(\mathrm{year})$ & 0.70 & 0.50 & 1.30 & 1.34 & 12.60 & 0.05 \\
Gross Drainage Area $\left(\mathrm{km}^{2}\right)$ & $3.36 \times 10^{3}$ & $5.32 \times 10^{4}$ & $1.36 \times 10^{5}$ & $4.86 \times 10^{4}$ & $2.33 \times 10^{4}$ & $2.68 \times 10^{3}$ \\
Effective Drainage Area km $\left.{ }^{2}\right)$ & $1.28 \times 10^{3}$ & $1.38 \times 10^{4}$ & $8.69 \times 10^{4}$ & $1.22 \times 10^{4}$ & $2.90 \times 10^{3}$ & $1.25 \times 10^{3}$ \\
\hline
\end{tabular}


730 Table 2. Summary of scenario analysis depicting changes in total algae, surface bloom

731 intensity, and water clarity under different hydrologic regimes, increases in water

732 temperature, or water-column nutrient content. Changes are depicted with estimated

733 values of total algae $\left(\mu \mathrm{g} \mathrm{Chl} \mathrm{L}{ }^{-1}\right)$, surface blooms $\left(\mu \mathrm{g} \mathrm{Chl} \mathrm{L}^{-1}\right)$, and water clarity (depth,

$734 \mathrm{~m})$ and percentage change in each response variable under each scenario. Further, values

735 are given for each variable as estimates of current conditions from the model, and as

736 measured averages of current conditions. Factor interactions were linear combinations of

737 expected change and are not presented.

738

739

\begin{tabular}{l|cc|cc|cc}
\hline & $\begin{array}{c}\text { Total Algae } \\
\left(\mu \mathrm{g} \mathrm{L}^{-1}\right)\end{array}$ & $\begin{array}{c}\% \\
\text { change }\end{array}$ & $\begin{array}{c}\text { Surface } \\
\text { Blooms } \\
\left(\mu \mathrm{g} \mathrm{L}^{-1}\right)\end{array}$ & $\begin{array}{c}\% \\
\text { change }\end{array}$ & $\begin{array}{c}\text { Water } \\
\text { Clarity }(\mathrm{m})\end{array}$ & $\begin{array}{c}\% \\
\text { change }\end{array}$ \\
\hline & 20.3 & 7.3 & 23.5 & 10.1 & 1.5 & 3.3 \\
$1 \%$ of inflow & 19.9 & 5.6 & 22.9 & 7.7 & 1.6 & 2.5 \\
$25 \%$ of Inflow & 19.6 & 3.7 & 22.4 & 5.1 & 1.6 & 1.7 \\
$50 \%$ of Inflow & 18.2 & -3.7 & 20.3 & -5.1 & 1.6 & -1.7 \\
$150 \%$ Inflow & 17.5 & -7.4 & 19.2 & -10.2 & 1.7 & -3.3 \\
$200 \%$ Inflow & 6.3 & -66.7 & 1.7 & -91.9 & 2.1 & -29.9 \\
$1000 \%$ of Inflow & 21.7 & 14.6 & 23.8 & 11.5 & 1.6 & 0.2 \\
$1{ }^{\circ} \mathrm{C}$ Temp. Increase & 24.4 & 29.3 & 26.3 & 22.9 & 1.6 & 0.4 \\
$2{ }^{\circ} \mathrm{C}$ Temp. Increase & 27.2 & 43.9 & 28.7 & 34.4 & 1.6 & 0.6 \\
$3{ }^{\circ} \mathrm{C}$ Temp. Increase & 29.9 & 58.6 & 31.2 & 45.9 & 1.6 & 0.8 \\
$4{ }^{\circ} \mathrm{C}$ Temp. Increase & 32.7 & 73.3 & 33.6 & 57.4 & 1.6 & 0.9 \\
$5{ }^{\circ} \mathrm{C}$ Temp. Increase & 13.4 & -29.0 & 16.2 & -23.9 & 1.6 & -0.6 \\
$10 \%$ current nutrients & 14.3 & -24.2 & 17.1 & -19.9 & 1.6 & -0.5 \\
$25 \%$ current nutrients & 15.8 & -16.1 & 18.5 & -13.3 & 1.6 & -0.3 \\
$50 \%$ current nutrients & 25.0 & 32.2 & 27.0 & 26.5 & 1.6 & 0.6 \\
$200 \%$ current nutrients & 31.1 & 64.5 & 32.7 & 53.1 & 1.6 & 1.2 \\
$300 \%$ current nutrients & & & & & & \\
\hline
\end{tabular}




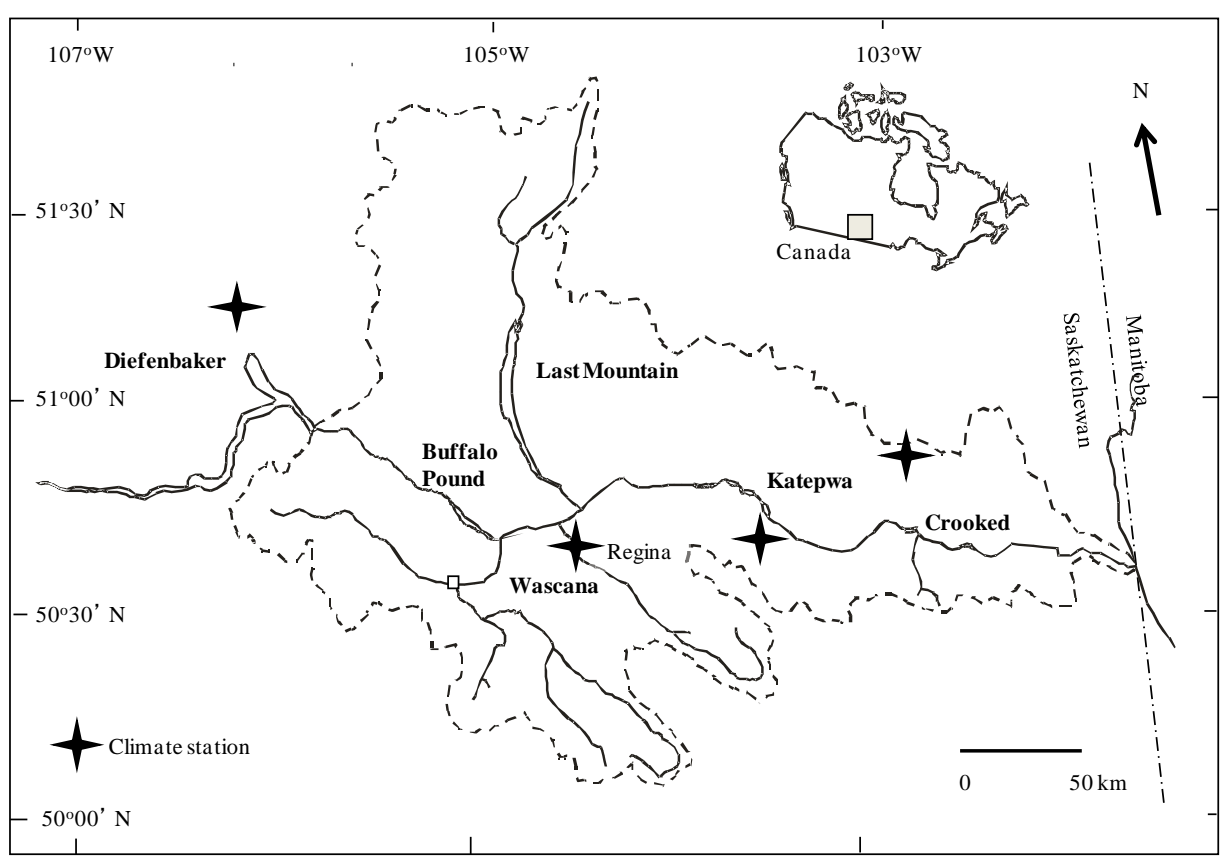

751

752 Fig. 1. The Qu'Appelle River catchment, Saskatchewan, Canada, originates at Lake

753 Diefenbaker and flows eastward through Buffalo Pound, Katepwa, and Crooked lakes.

754 Last Mountain Lake and Wascana Lake enter the river through tributary creeks.

755 Limnological characteristics of study lakes were monitored bi-weekly during the ice-free

756 season (May-August) from 1995-2010. Four climate stations indicated with crosses

757 provided weather data for the same interval (1995-2010). 

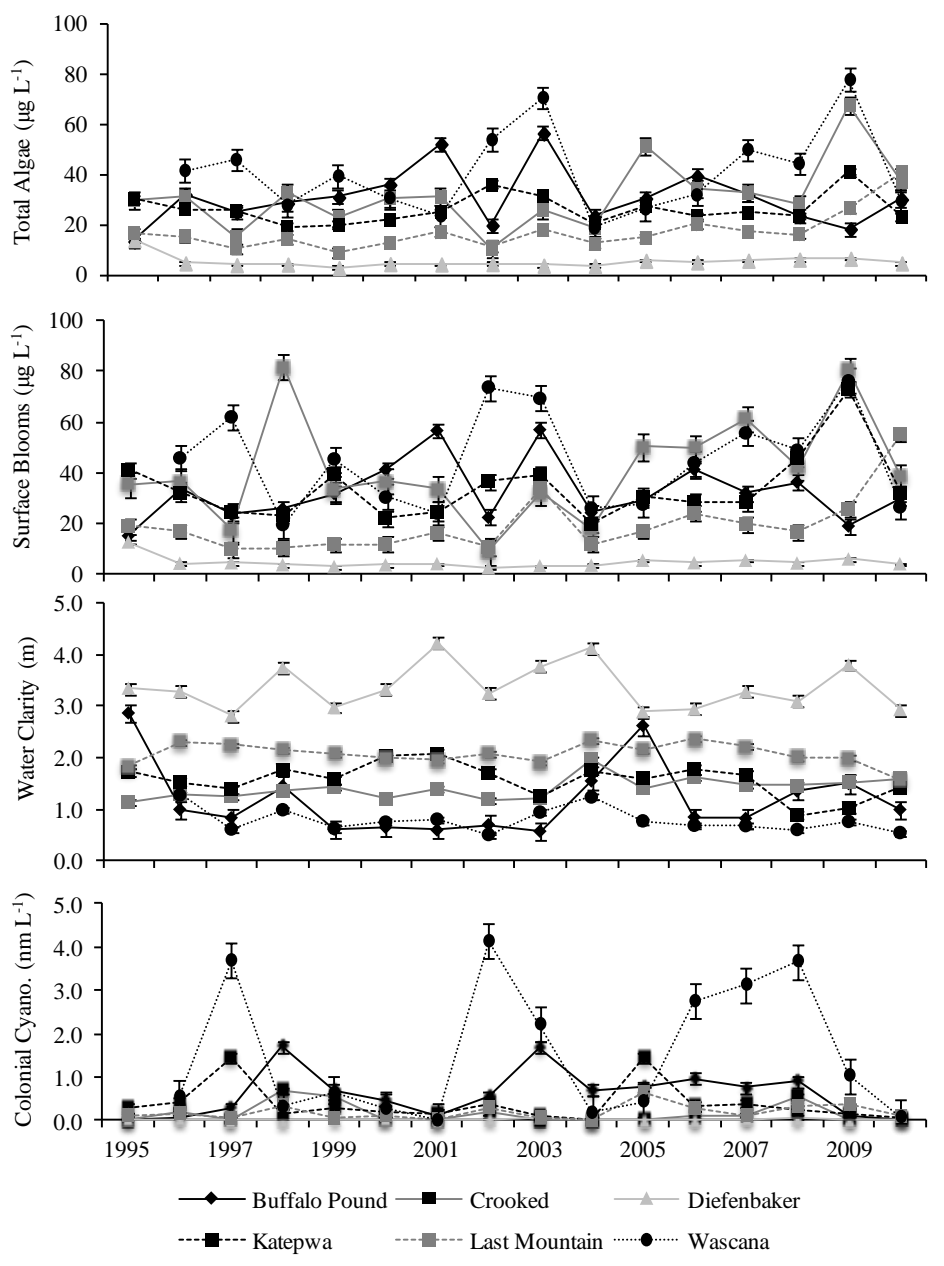

776 Fig. 2. Time series of four indices of water quality: total algae $\left(\mu \mathrm{g} \mathrm{L}^{-1}\right)$, surface blooms

$777\left(\mu \mathrm{g} \mathrm{L}^{-1}\right)$, water clarity $(\mathrm{m})$, and colonial cyanobacteria (nmoles myxoxanthophyll $\left.\mathrm{L}^{-1}\right)$.

778 Data are based on seasonal (May-August) means \pm standard error (SE) for the interval

779 1995-2010 and were collected from six study lakes; Buffalo Pound, Crooked,

780 Diefenbaker, Katepwa, Last Mountain, and Wascana. There were no statistically

781 significant trends in any time series (see Methods). 
A) Water Quality Variables

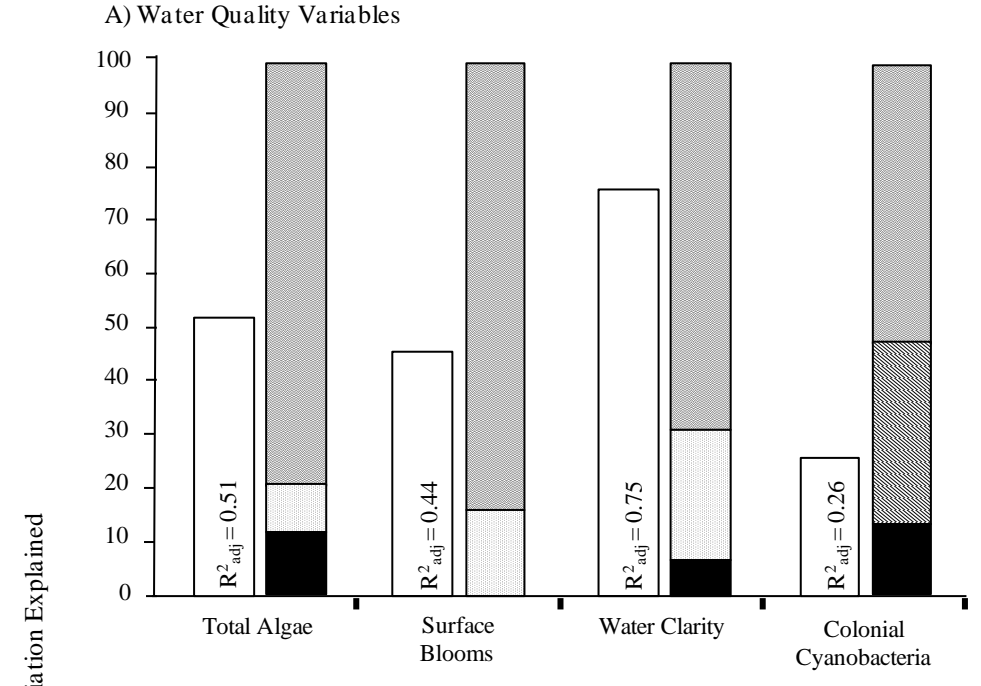

$$
\text { B) Limnological Drivers of Water Quality }
$$

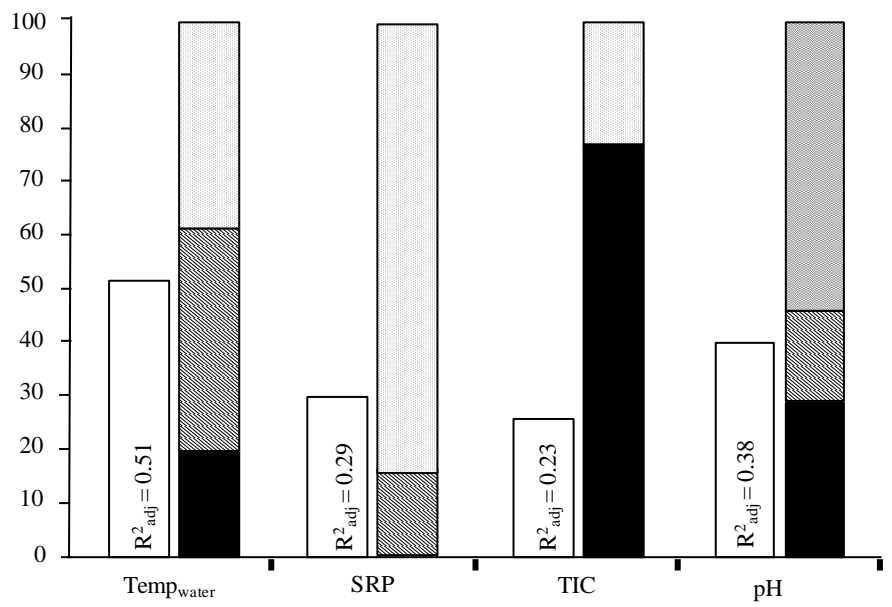

800 explained (filled) by multiple regression models describing variation in mean summer

801 (May-August) (A) water quality parameters, including total algae, surface blooms, water

802 clarity, and potentially-toxic colonial cyanobacteria, or (B) key limnological

803 characteristics, including water temperature $\left(\mathrm{T}_{\text {water }}\right)$, soluble reactive phosphorus

804 concentration (SRP), total inorganic carbon content (TIC), and pH. Model performance

805 was evaluated by adjusted coefficient of determination $\left(R_{\text {adj }}^{2}\right)$. Significant $(p<0.05)$

806 explanatory variables were selected by forward selection multiple regression based on 
8079999 permutations and were classified into categories associated with variation in climate

808 systems (black), regional meteorology (diagonal lines), river hydrology (dotted), and

809 internal lake characteristics (waves).

810

811 

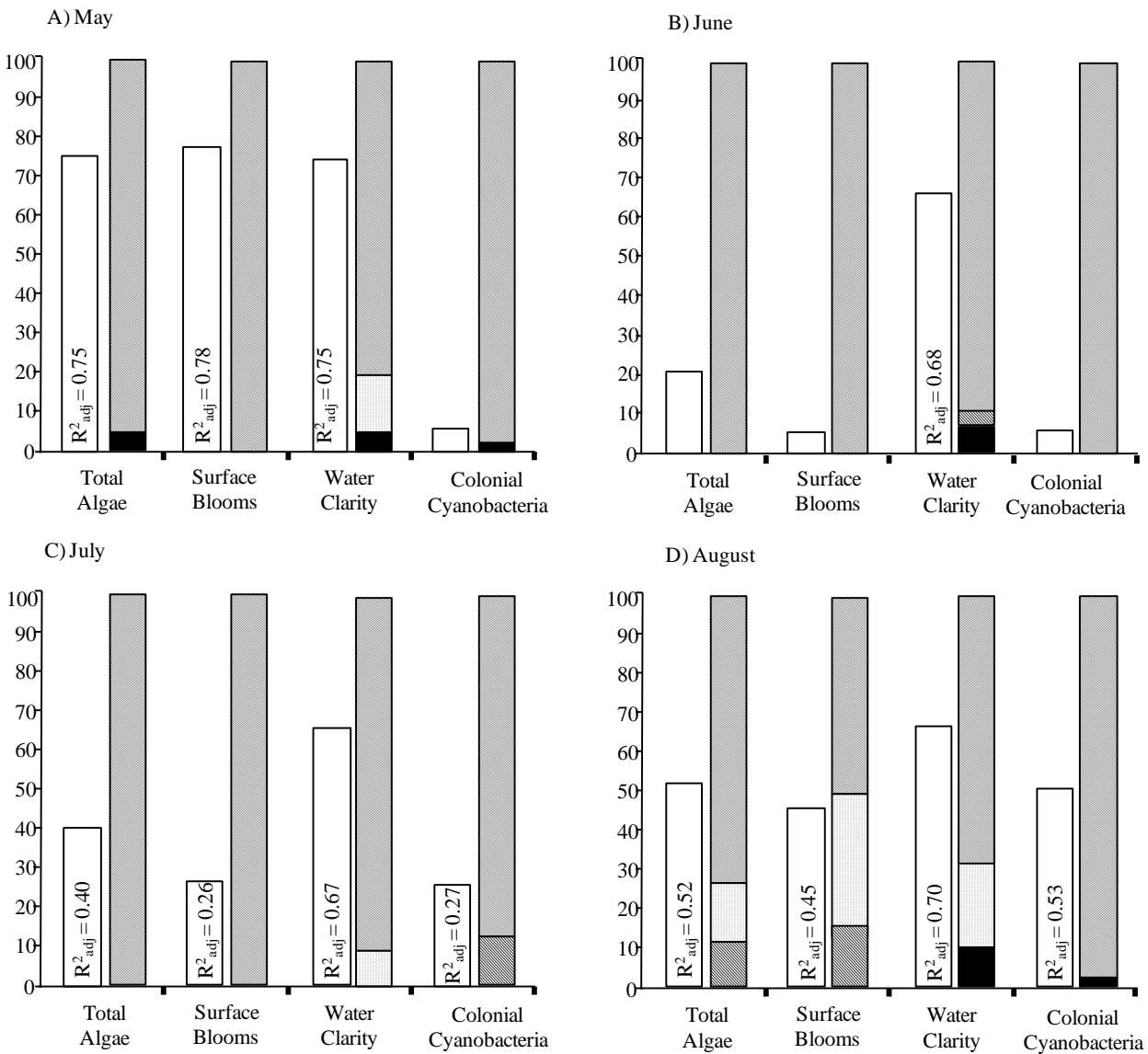

825

826 Fig. 4. Total explained variation (white) and proportion of non-residual variation

827 explained (filled) by multiple regression models describing variation in mean monthly

828 estimates of total algal abundance, surface bloom intensity, water clarity, and density of

829 colonial cyanobacteria for data from (A) May, (B) June, (C) July, or (D) August. Model

830 performance was evaluated by adjusted coefficient of determination $\left(R^{2}{ }_{\text {adj }}\right)$. Significant

$831(p<0.05)$ explanatory variables were selected by forward selection multiple regression

832 and were classified into categories associated with variation in climate systems (black),

833 regional meteorology (diagonal lines), river hydrology (dotted), and internal lake

834 characteristics (waves). 
B) Primary predictors of important limnological predictor variables

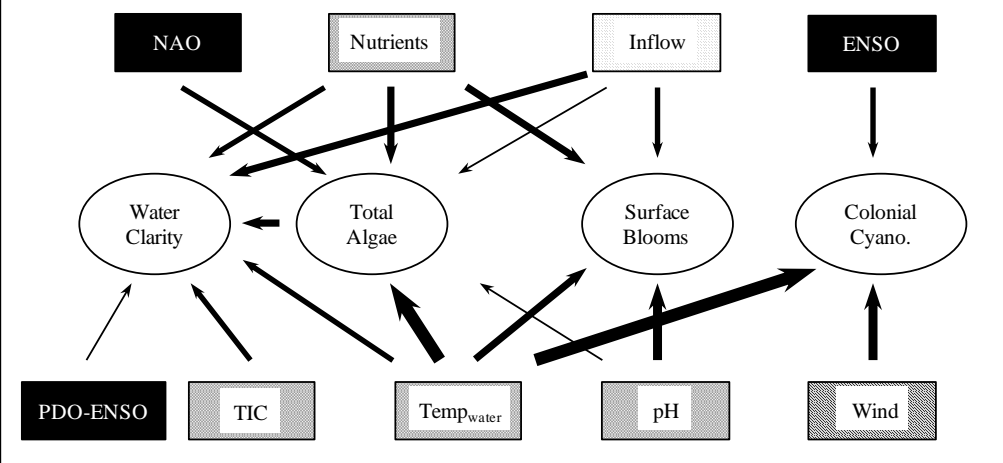

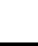

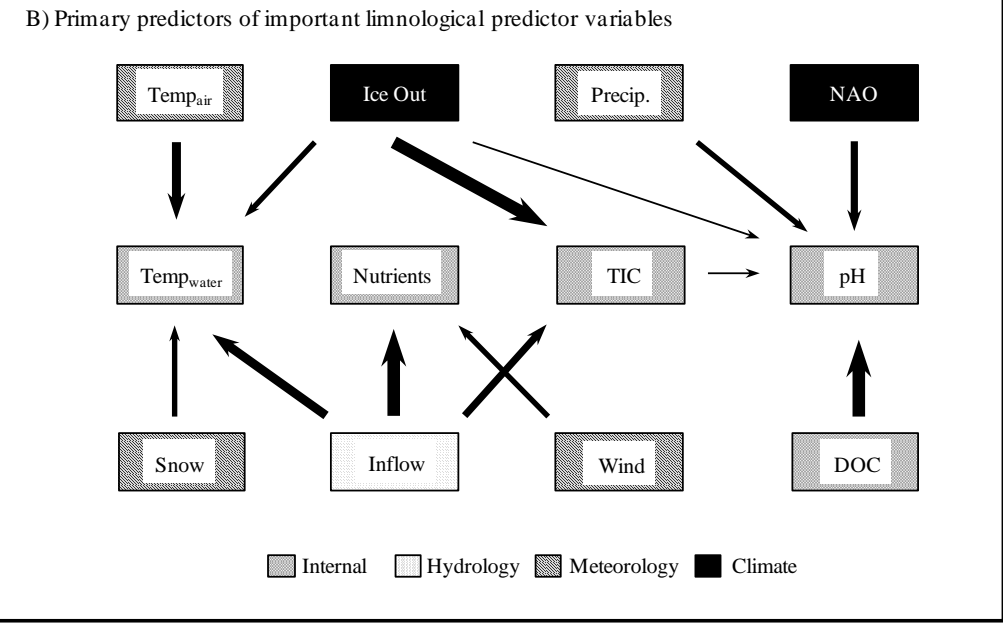

849 Fig. 5. A schematic representation of the predictive relationships between explanatory

850 and response variables for (A) water quality and (B) important internal lake

851 characteristics. Water quality response variables are depicted with open ovals. All

852 predictor variables are depicted with shaded rectangles and are classified by general

853 category: climate systems (black), regional meteorology (diagonal lines), river hydrology

854 (dotted), and internal lake characteristics (waves). Arrow thickness increases with

855 percentage of non-residual variation explained for each model. Interactions between

856 water quality variables were not measured except for that between total algal abundance

857 and water clarity. 

meteorology, river hydrology, and internal lake characteristics. Mean values were computed at seasonal resolution (May-August), from 1995-2010 \pm standard deviation (SD). Ranges are presented as the maximum and minimum seasonal values from 1995-2010. PDO = Pacific decadal Oscillation index, ENSO = El Niño-Southern Oscillation index, NAO = winter North Atlantic Oscillation index, $\mathrm{SRP}=$ soluble reactive phosphorus, TDP = total dissolved phosphorus, DOC = dissolved organic carbon, DIC = dissolved inorganic carbon, and zoop. $=$ zooplankton.

\begin{tabular}{|c|c|c|c|c|c|c|c|c|}
\hline Category & Explanatory variable & & Buffalo Pound & Crooked & Diefenbaker & Katepwa & Last Mountain & Wascana \\
\hline \multirow[t]{5}{*}{ Climate } & \multirow[t]{2}{*}{ Ice Out, day of year (DOY) } & Mean \pm SD & $110.38 \pm 6.40$ & $114.02 \pm 5.05$ & $120.69 \pm 8.76$ & $114.06 \pm 7.36$ & $112.94 \pm 6.59$ & $105.97 \pm 3.09$ \\
\hline & & Range & $95-120$ & $107-123$ & 108-121 & 103-128 & $105-128$ & $100-110$ \\
\hline & \multirow[t]{3}{*}{ Climate Teleconnections } & & PDO & ENSO & $\mathrm{NAO}$ & & & \\
\hline & & Mean \pm SD & $0.03 \pm 0.74$ & $0.54 \pm 6.24$ & $-4.82 \pm 12.79$ & & & \\
\hline & & Range & $-1.29-1.46$ & $-11.76-10.17$ & $-41.74-0.39$ & & & \\
\hline \multirow[t]{9}{*}{ Meteorology } & \multirow[t]{2}{*}{ Summer Temperature $\left({ }^{\circ} \mathrm{C}\right)$} & Mean \pm SD & $15.62 \pm 1.06$ & $15.17 \pm 1.03$ & $15.89 \pm 0.97$ & $14.72 \pm 1.11$ & $15.62 \pm 1.06$ & $15.62 \pm 1.06$ \\
\hline & & Range & $\begin{array}{c}13.20-17.08 \\
56.95 \pm 14.49\end{array}$ & $\begin{array}{c}12.60-16.83 \\
64.85 \pm 20.48\end{array}$ & $\begin{array}{c}14.08-17.33 \\
50.50 \pm 16.53\end{array}$ & $\begin{array}{l}12.20-16.25 \\
56.34 \pm 23.07\end{array}$ & $\begin{array}{l}13.20-17.08 \\
56.95 \pm 14.49\end{array}$ & $\begin{array}{l}13.20-17.08 \\
56.95 \pm 14.49\end{array}$ \\
\hline & $\begin{array}{l}\text { Precipitation (May-August) } \\
\quad(\mathrm{mm})\end{array}$ & $\begin{array}{l}\text { Mean } \pm \text { SD } \\
\text { Range }\end{array}$ & $28.95-75.60$ & $25.55-99.88$ & $26.5-80.53$ & $18.9-85.40$ & $28.95-75.60$ & $28.95-75.60$ \\
\hline & \multirow[t]{2}{*}{ Annual Precipitation (mm) } & Mean \pm SD & $32.32 \pm 6.43$ & $36.87 \pm 8.91$ & $29.46 \pm 8.55$ & $33.62 \pm 10.16$ & $32.32 \pm 6.43$ & $32.32 \pm 6.43$ \\
\hline & & Range & $21.64-45.33$ & $19.73-57.88$ & $16.54-44.51$ & $16.96-55.82$ & $21.64-45.33$ & $21.64-45.33$ \\
\hline & \multirow[t]{2}{*}{ Winter Snowfall (mm) } & Mean \pm SD & $14.91 \pm 4.71$ & $15.25 \pm 8.00$ & $13.29 \pm 5.48$ & $17.03 \pm 6.89$ & $14.91 \pm 4.71$ & $14.91 \pm 4.71$ \\
\hline & & Range & $6.87-25.67$ & $7.07-39.87$ & $3.2-21.20$ & $4.27-30.87$ & $6.87-25.67$ & $6.87-25.67$ \\
\hline & \multirow[t]{2}{*}{ Wind speed $\left(\mathrm{km} \mathrm{h}^{-1}\right)$} & Mean \pm SD & $14.98 \pm 2.64$ & $14.16 \pm 5.24$ & $11.90 \pm 3.67$ & $12.06 \pm 3.09$ & $15.50 \pm 3.38$ & $9.28 \pm 3.67$ \\
\hline & & Range & $10.875-20.00$ & $6.5-22.44$ & $7.12-20.71$ & $6.67-18.75$ & $9.5-21.88$ & $4.25-17.03$ \\
\hline \multirow[t]{4}{*}{ Hydrology } & \multirow[t]{2}{*}{ Annual Inflow $\left(\right.$ dam $\left.^{3}\right)$} & Mean \pm SD & $1.3 \mathrm{E} 5 \pm 2.2 \mathrm{E} 4$ & $2.8 \mathrm{E} 5 \pm 1.7 \mathrm{E} 5$ & $7.0 \mathrm{E} 6 \pm 2.6 \mathrm{E} 6$ & $2.4 \mathrm{E} 5 \pm 1.5 \mathrm{E} 5$ & $1.4 \mathrm{E} 5 \pm 6.1 \mathrm{E} 4$ & $3.0 \mathrm{E} 4 \pm 3.2 \mathrm{E} 4$ \\
\hline & & Range & $1.0 \mathrm{E} 5-1.9 \mathrm{E} 5$ & 7.4E5 - 5.9E5 & $2.7 \mathrm{E} 6-1.2 \mathrm{E} 7$ & $6.0 \mathrm{E} 4-5.1 \mathrm{E} 5$ & 7.9E4 - 2.4E5 & 1.7E3- 1.1E5 \\
\hline & \multirow[t]{2}{*}{ Residence time (yr) } & Mean \pm SD & $0.73 \pm 0.09$ & $0.62 \pm 0.46$ & $1.60 \pm 0.72$ & $1.39 \pm 1.04$ & $11.62 \pm 4.20$ & $0.08 \pm 0.11$ \\
\hline & & Range & $0.60-0.90$ & $0.10-1.94$ & $0.82-3.66$ & $0.44-4.37$ & $5.08-18.01$ & $0.01-0.41$ \\
\hline Internal Lake & $\operatorname{SRP}\left(\mu \mathrm{g} \mathrm{L}^{-1}\right)$ & Mean \pm SD & $30.70 \pm 63.27$ & $82.89 \pm 42.84$ & $10.52 \pm 12.28$ & $108.88 \pm 54.57$ & $24.25 \pm 17.98$ & $223.79 \pm 119.63$ \\
\hline
\end{tabular}


Characteristics

\begin{tabular}{|c|c|c|}
\hline \multirow[t]{2}{*}{$\operatorname{TDP}\left(\mu \mathrm{g} \mathrm{L}^{-1}\right)$} & Mean \pm SD & $50.25 \pm 85.82$ \\
\hline & Range & $15.56-370.61$ \\
\hline \multirow[t]{2}{*}{$\mathrm{NO}_{3}\left(\mu \mathrm{g} \mathrm{L}^{-1}\right)$} & Mean \pm SD & $76.87 \pm 80.30$ \\
\hline & Range & $10.22-305$ \\
\hline \multirow[t]{2}{*}{$\mathrm{NH}_{4}\left(\mu \mathrm{g} \mathrm{L}^{-1}\right)$} & Mean \pm SD & $32.86 \pm 44.87$ \\
\hline & Range & $0-158.75$ \\
\hline \multirow[t]{2}{*}{$\mathrm{DOC}\left(\mathrm{mg} \mathrm{L}^{-1}\right)$} & Mean \pm SD & $7.49 \pm 3.30$ \\
\hline & Range & $3.62-17.06$ \\
\hline \multirow[t]{2}{*}{$\mathrm{TIC}\left(\mathrm{mg} \mathrm{L}^{-1}\right)$} & Mean \pm SD & $32.29 \pm 6.17$ \\
\hline & Range & $15.94-39.47$ \\
\hline \multirow[t]{2}{*}{$\mathrm{pH}$} & Mean \pm SD & $8.72 \pm 0.43$ \\
\hline & Range & $7.95-9.49$ \\
\hline \multirow[t]{2}{*}{ Water Temperature $\left({ }^{\circ} \mathrm{C}\right)$} & Mean \pm SD & $17.66 \pm 0.96$ \\
\hline & Range & $15.59-19.39$ \\
\hline \multirow[t]{2}{*}{$\mathrm{O}_{2}\left(\mathrm{mg} \mathrm{L}^{-1}\right)$} & Mean \pm SD & $8.14 \pm 1.40$ \\
\hline & Range & $5.29-9.84$ \\
\hline \multirow[t]{2}{*}{ Conductivity $\left(\mu \mathrm{S} \mathrm{cm}^{-1}\right)$} & Mean \pm SD & $468.7 \pm 80.5$ \\
\hline & Range & $377.8-704.9$ \\
\hline \multirow[t]{2}{*}{ Total Zoopl. (ind $\mathrm{L}^{-1}$ ) } & Mean \pm SD & $115.09 \pm 115.78$ \\
\hline & Range & $5.06-399.85$ \\
\hline \multirow{2}{*}{$\begin{array}{l}\text { Herbivores and Omnivores } \\
\quad\left(\text { ind } \mathrm{L}^{1}\right)\end{array}$} & Mean \pm SD & $83.43 \pm 83.02$ \\
\hline & Range & $3.77-328.26$ \\
\hline \multirow[t]{2}{*}{ Large Cladocera (ind L ${ }^{-1}$ ) } & Mean \pm SD & $21.80 \pm 16.91$ \\
\hline & Range & $1.22-51.88$ \\
\hline \multirow[t]{2}{*}{ Small Cladocera (ind $\mathrm{L}^{-1}$ ) } & Mean \pm SD & $23.36 \pm 45.19$ \\
\hline & Range & $0.03-185.16$ \\
\hline \multirow[t]{2}{*}{ Copepods (ind $\mathrm{L}^{-1}$ ) } & Mean \pm SD & $31.31 \pm 26.23$ \\
\hline & Range & $2.48-89.44$ \\
\hline Chlorophyll a $\left(\mu \mathrm{g} \mathrm{L}^{-1}\right)$ & Mean \pm SD & $30.86 \pm 11.40$ \\
\hline
\end{tabular}

$\begin{array}{ccccc}9.14-149.11 & 0.1-47.53 & 9.13-240.13 & 3.44-72.55 & 67.44-450.67 \\ 116.07 \pm 42.26 & 18.93 \pm 18.05 & 144.45 \pm 41.06 & 48.30 \pm 27.32 & 301.49 \pm 162.23 \\ 47.24-171.38 & 3.03-68.57 & 58.85-233.02 & 23.31-132.55 & 103.34-597.89 \\ 93.85 \pm 99.44 & 167.22 \pm 93.67 & 204.83 \pm 183.96 & 61.14 \pm 57.06 & 153.78 \pm 135.34 \\ 0-391.43 & 1-307.67 & 0.56-573.44 & 5.75-167.56 & 7.76-436.21 \\ 30.49 \pm 28.03 & 18.55 \pm 20.94 & 75.32 \pm 84.19 & 28.40 \pm 23.99 & 81.42 \pm 113.95 \\ 0-107.14 & 0.2-77.5 & 1.89-351.25 & 0.2-91.25 & 0.2-446.25 \\ 13.28 \pm 5.95 & 6.76 \pm 3.16 & 13.70 \pm 5.10 & 16.44 \pm 7.59 & 17.90 \pm 6.67 \\ 5.78-33.02 & 3.72-14.93 & 6.58-30.17 & 7.01-34.05 & 10.88-40.46 \\ 49.82 \pm 7.90 & 33.56 \pm 4.93 & 48.60 \pm 7.55 & 57.86 \pm 7.85 & 40.16 \pm 7.81 \\ 35.22-66.09 & 27.03-45.71 & 40.94-67.69 & 49.02-78.05 & 27.71-54.38 \\ 8.82 \pm 0.41 & 8.66 \pm 0.45 & 8.97 \pm 0.44 & 8.82 \pm 0.38 & 9.04 \pm 0.33 \\ 8.24-9.51 & 8.03-9.43 & 8.28-9.70 & 8.29-9.51 & 8.36-9.69 \\ 16.72 \pm 1.18 & 13.16 \pm 0.97 & 13.27 \pm 1.09 & 15.31 \pm 1.19 & 17.67 \pm 1.10 \\ 14.43-18.58 & 11.41-14.59 & 11.61-15.45 & 13.30-17.70 & 16.35-19.97 \\ 7.94 \pm 1.43 & 8.98 \pm 1.64 & 7.16 \pm 1.01 & 8.04 \pm 1.40 & 8.13 \pm 1.03 \\ 4.27-9.86 & 5.39-11.05 & 5.45-9.34 & 4.44-9.66 & 6.25-9.35 \\ 1210.7 \pm 148.7 & 411.0 \pm 134.7 & 1135.5 \pm 159.3 & 1776.2 \pm 177.6 & 900.3 \pm 270.7 \\ 930.5-1484.0 & 309.1-697.8 & 798.6-1452.1 & 1579.2-2178.7 & 515.1-1436.7 \\ 67.26 \pm 25.30 & 23.84 \pm 14.48 & 66.82 \pm 33.74 & 43.89 \pm 13.73 & 67.18 \pm 46.83 \\ 29.72-117.45 & 10.41-61.17 & 20.57-136.66 & 23.89-70.56 & 21.60-206.73 \\ 58.98 \pm 22.99 & 18.56 \pm 11.55 & 59.91 \pm 28.79 & 38.55 \pm 13.53 & 48.42 \pm 32.47 \\ 25.52-105.75 & 7.68-44.22 & 17.16-114.07 & 20.56-65.67 & 16.67-152.78 \\ 16.47 \pm 10.18 & 4.53 \pm 2.35 & 10.66 \pm 5.30 & 11.21 \pm 4.09 & 14.60 \pm 9.84 \\ 3.87-39.64 & 1.87-9.34 & 3.36-20.36 & 6.10-21.78 & 4.53-36.23 \\ 1.42 \pm 1.83 & 2.61 \pm 1.61 & 2.22 \pm 3.07 & 1.94 \pm 1.65 & 6.07 \pm 15.59 \\ 0-5.76 & 0.46-5.36 & 0.08-11.54 & 0.28-5.64 & 0.10-60.35 \\ 43.29 \pm 17.04 & 11.88 \pm 9.56 & 46.79 \pm 21.62 & 25.43 \pm 10.21 & 28.59 \pm 15.48 \\ 22.02-76.67 & 4.80-35.87 & 13.64-92.54 & 12.30-50.49 & 11.44-70.69 \\ 31.24 \pm 13.54 & 5.38 \pm 2.53 & 26.24 \pm 5.97 & 17.04 \pm 7.61 & 40.89 \pm 16.99 \\ & & & & \\ & & & & \end{array}$




\begin{tabular}{|c|c|c|c|c|c|c|c|}
\hline & Range & $13.56-56.61$ & $10.18-67.65$ & $2.95-14.12$ & $19.12-41.26$ & $8.69-40.88$ & $18.75-77.96$ \\
\hline \multirow[t]{2}{*}{ Clarity (Secchi depth m) } & Mean \pm SD & $1.18 \pm 0.70$ & $1.41 \pm 0.21$ & $3.36 \pm 0.44$ & $1.57 \pm 0.32$ & $2.08 \pm 0.21$ & $0.79 \pm 0.23$ \\
\hline & Range & $0.57-2.87$ & $1.14-1.98$ & $2.81-4.22$ & $0.88-2.07$ & $1.58-2.36$ & $0.51-1.28$ \\
\hline Cyanobacteria density & Mean \pm SD & $0.62 \pm 0.53$ & $0.16 \pm 0.23$ & $0.02 \pm 0.02$ & $0.38 \pm 0.43$ & $0.19 \pm 0.17$ & $1.54 \pm 1.54$ \\
\hline (nmoles myxo. $\mathrm{L}^{-1}$ ) & Range & $0.01-1.71$ & $0-0.68$ & $0-0.06$ & $0-1.44$ & $0-0.64$ & $0-4.13$ \\
\hline
\end{tabular}


Supporting Information Table S2. Summary of regression models predicting four indices of water quality; concentrations of total algae, surface blooms, water clarity, and concentrations of colonial cyanobacteria. Models are based on 16 years of monitoring in six study lakes (May-August, 1995-2010). Model performance is summarized using an adjusted coefficient of determination ( $R^{2}$ adj), and models were significant with a probability level of $p$. Multiple regression models include predictor variables for each water quality index selected using a Monte Carlo forward selection. SRP $=$ soluble reactive phosphorus concentration, $\mathrm{NAO}=$ winter North Atlantic Oscillation index, $\mathrm{TIC}=$ total inorganic carbon concentration, wind $=$

871 mean wind speed, ENSO = El Niño-Southern Oscillation index, and temp. $=$ temperature.

\begin{tabular}{|c|c|c|c|c|c|c|c|c|c|c|}
\hline \multirow[t]{2}{*}{ Water Quality Variable } & \multicolumn{3}{|c|}{ Linear Regression } & \multicolumn{3}{|l|}{ Multiple Regression } & \\
\hline & $R_{\text {adj }}^{2}$ & $p$ & slope & & $R_{\text {adj }}^{2}$ & $p$ & Predictor & Coefficient & $\begin{array}{c}\% \text { Total } \\
\text { Variation } \\
\text { Explained }\end{array}$ & $\begin{array}{c}\% \text { Explained } \\
\text { Variation }\end{array}$ \\
\hline \multirow[t]{2}{*}{ Total algae } & 0.02 & 0.09 & 0.60 & Water Temperature + SRP - NAO - Inflow + pH & 0.51 & $<0.00001$ & $\begin{array}{l}\text { Water Temp. } \\
\text { SRP }\end{array}$ & $\begin{array}{l}2.77 \\
3.88\end{array}$ & $\begin{array}{l}23.5 \\
13.1\end{array}$ & $\begin{array}{l}45.6 \\
25.6\end{array}$ \\
\hline & & & & & & & $\begin{array}{l}\text { NAO } \\
\text { Inflow } \\
\text { pH } \\
\text { Residual } \\
\text { Intercept }\end{array}$ & $\begin{array}{c}-0.22 \\
0.00 \\
5.70\end{array}$ & $\begin{array}{c}6.0 \\
4.5 \\
4.3 \\
48.6\end{array}$ & $\begin{array}{c}11.7 \\
8.7 \\
8.4\end{array}$ \\
\hline \multirow[t]{3}{*}{ Surface Blooms } & 0.02 & 0.08 & 0.77 & $\mathrm{pH}+$ Water Temperature + SRP - Inflow & 0.44 & $<0.00001$ & $\mathrm{pH}$ & 12.40 & 15.1 & 34.2 \\
\hline & & & & & & & $\begin{array}{l}\text { Water Temp. } \\
\log _{10} \text { SRP } \\
\text { Inflow } \\
\text { Residual }\end{array}$ & $\begin{array}{l}2.45 \\
3.61 \\
0.00\end{array}$ & $\begin{array}{c}12.2 \\
9.7 \\
7.0 \\
56.0\end{array}$ & $\begin{array}{l}27.8 \\
22.0 \\
15.9\end{array}$ \\
\hline & & & & & & & Intercept & -130.00 & & \\
\hline \multirow[t]{8}{*}{ Water Clarity } & 0 & 0.57 & 0.00 & - Chl a + Inflow - SRP + TIC - Water Temperature + & 0.75 & $<0.00001$ & Chl a & -0.01 & 18.7 & 24.9 \\
\hline & & & & ENSO $*$ PDO & & & Inflow & 0.00 & 18.3 & 24.4 \\
\hline & & & & & & & $\log _{10} \mathrm{SRP}$ & -0.06 & 14.7 & 19.6 \\
\hline & & & & & & & TIC & 0.01 & 10.4 & 13.9 \\
\hline & & & & & & & Water Temp. & -0.03 & 7.9 & 10.5 \\
\hline & & & & & & & PDO*ENSO & 0.01 & 5.0 & 6.7 \\
\hline & & & & & & & Residual & & 25.0 & \\
\hline & & & & & & & Intercept & 1.54 & & \\
\hline \multirow[t]{5}{*}{ Colonial Cyanobacteria } & 0 & 0.63 & 0.01 & Water Temperature - Wind - ENSO & 0.26 & $<0.00001$ & Water Temp. & 0.17 & 13.7 & 52.7 \\
\hline & & & & & & & Wind & -0.07 & 8.5 & 32.7 \\
\hline & & & & & & & ENSO & -0.03 & 3.8 & 14.5 \\
\hline & & & & & & & Residual & & 74.0 & \\
\hline & & & & & & & Intercept & -1.19 & & \\
\hline
\end{tabular}


873 Supporting Information Table S3. Summary of regression models predicting four limnological characteristics; water temperature, soluble reactive

874 P content, TIC, and pH. Models are based on 16 years of monitoring in six study lakes (May-August, 1995-2010). Model performance is

875 summarized using an adjusted coefficient of determination $\left(R^{2}\right.$ adj $)$, and models were significant with a probability level of $p$. Multiple regression

876 models include predictor variables for each water quality index selected using a Monte Carlo forward selection. Temp. $=$ temperature, ice out $=$ day

877 of year of ice melt, $\mathrm{DOC}=$ dissolved organic carbon concentration, $\mathrm{NAO}=$ winter North Atlantic Oscillation index, and precip. $=$ precipitation.

\begin{tabular}{|c|c|c|c|c|c|c|c|c|c|c|}
\hline \multirow[t]{2}{*}{ Water Quality Variable } & \multicolumn{3}{|c|}{ Linear Regression } & \multicolumn{3}{|l|}{ Multiple Regression } & \\
\hline & $R_{\text {adj }}^{2}$ & $p$ & slope & & $R_{\text {adj }}^{2}$ & $p$ & Predictor & Coefficient & $\begin{array}{c}\% \text { Total } \\
\text { Variation } \\
\text { Explained }\end{array}$ & $\begin{array}{c}\% \text { Explained } \\
\text { Variation }\end{array}$ \\
\hline \multirow[t]{6}{*}{ Water Temperature } & 0 & 0.97 & 0.00 & - Inflow + Summer Air Temperature - Ice Out - & 0.51 & $<0.00001$ & Inflow & 0.00 & 19.8 & 38.8 \\
\hline & & & & Snow & & & Air Temp. & 0.71 & 15.7 & 30.7 \\
\hline & & & & & & & Ice Out & -0.09 & 9.8 & 1929 \\
\hline & & & & & & & Snow & -0.08 & 5.7 & 11.23 \\
\hline & & & & & & & Intercept & 16.20 & & \\
\hline & & & & & & & Residual & & 49.0 & \\
\hline Soluble Reactive & 0 & 0.74 & 0.01 & - Inflow - Wind & 0.29 & $<0.00001$ & Inflow & 0.00 & 24.2 & 83.4 \\
\hline \multirow[t]{3}{*}{ Phosphorus (SRP) } & & & & & & & Wind & -0.07 & 4.8 & 16.6 \\
\hline & & & & & & & Intercept & 4.93 & & \\
\hline & & & & & & & Residual & & 71.0 & \\
\hline \multirow{4}{*}{$\begin{array}{l}\text { Total Inorganic Carbon } \\
\text { (TIC) }\end{array}$} & 0 & 0.74 & 0.09 & Ice Out - Inflow & 0.234 & $<0.00001$ & Ice Out & 0.49 & 18.2 & 77.6 \\
\hline & & & & & & & Inflow & 0.00 & 5.3 & 22.4 \\
\hline & & & & & & & Intercept & -8.30 & & \\
\hline & & & & & & & Residual & & 76.5 & \\
\hline \multirow[t]{7}{*}{$\mathrm{pH}$} & 0.28 & $<0.00001$ & 0.05 & DOC - NAO - Summer Precipitation - Ice Out - TIC & 0.38 & $<0.00001$ & DOC & 0.03 & 18.4 & 48.3 \\
\hline & & & & & & & NAO & -0.01 & 8.2 & 21.6 \\
\hline & & & & & & & Summer precip. & -0.01 & 6.3 & 16.5 \\
\hline & & & & & & & Ice Out & -0.01 & 2.8 & 7.4 \\
\hline & & & & & & & TIC & -0.01 & 2.4 & 6.23 \\
\hline & & & & & & & Intercept & 10.28 & & \\
\hline & & & & & & & Residual & & 61.9 & \\
\hline
\end{tabular}

